Winter 2015

\title{
Using a Community-Based Strategy to Address the Impacts of Globalization on Underwater Cultural Heritage Management in the Dominican Republic
}

Lydia Barbash-Riley

Indiana University Maurer School of Law, Ibarbash@indiana.edu

Follow this and additional works at: https://www.repository.law.indiana.edu/ijgls

Part of the Environmental Law Commons, Environmental Policy Commons, and the International Law Commons

\section{Recommended Citation}

Barbash-Riley, Lydia (2015) "Using a Community-Based Strategy to Address the Impacts of Globalization on Underwater Cultural Heritage Management in the Dominican Republic," Indiana Journal of Global Legal Studies: Vol. 22 : Iss. 1 , Article 11.

Available at: https://www.repository.law.indiana.edu/ijgls/vol22/iss1/11

This Note is brought to you for free and open access by the Law School Journals at Digital Repository @ Maurer Law. It has been accepted for inclusion in Indiana Journal of Global Legal Studies by an authorized editor of Digital Repository @ Maurer Law. For more information, please contact rvaughan@indiana.edu.

\section{$\Psi$}

JEROME HALL LAW LIBRARY

INDIANA UNIVERSITY

Maurer School of Law
Blooming ton 


\title{
Using a Community-Based Strategy to Address the Impacts of Globalization on Underwater Cultural Heritage Management in the Dominican Republic
}

\author{
LYDIA BARBASH-RILEY*
}

\begin{abstract}
This Note addresses the management of the Underwater Cultural Heritage (UCH) in the Dominican Republic as a case study of the effects of two aspects of globalization on cultural and environmental resource management in the developing world: the international convergence of values and the horizontal delegation of state power to private actors due to economic constraints. This Note posits that even as the global community of states moves toward a consensus on the ethical management of the UCH, this convergence combined with the global trend of horizontal delegation may incentivize some lesser-developed countries to deal with the economic pressures of resource management by permitting treasure hunting. To examine this phenomenon, this Note addresses national and international laws protecting the UCH, including Dominican laws and their actual consistency with the 2001 UNESCO Convention for the Protection of the Underwater Cultural Heritage. It then discusses how management in the Dominican Republic is not always in accord with either the country's own laws or the 2001 Convention to illustrate both the impacts of globalization on management of the UCH when government resources are scarce, and the resulting need for an extralegal, community-based solution. This Note
\end{abstract}

* Lydia Barbash-Riley, Editor-in-Chief, Indiana Journal of Global Legal Studies, Volume 22; JD 2016, Indiana University Maurer School of Law; MPA 2016, Indiana University School of Public and Environmental Affairs; BA 2007, University of WisconsinMadison. I would like to thank Ole Varmer for his invaluable assistance throughout the entire process of drafting and refining this Note, and Professor Charles Beeker for introducing me to the idea that cultural and biological conservation are two sides of the same coin. I would also like to express my special gratitude to the people of the Dominican Republic for welcoming me into their communities during my Peace Corps service and their tireless efforts to protect their heritage in the face of tremendous adversity.

Indiana Journal of Global Legal Studies Vol. 22 \#1 (Winter 2015)

(C) Indiana University Maurer School of Law 
concludes with a suggestion that the Dominican government, Dominican communities, and international actors consider a variant of CommonPool Resource Management known as Living Museums in the Sea incorporated into a Multilevel Environmental Governance framework as a potential solution to counteract the economic pressures on governments to allow treasure hunting while providing for long-term preservation of the UCH in this and other developing countries.

\section{INTRODUCTION}

The Greater Antilles, and in particular the island of Hispaniola, was the epicenter of the most transformative global event in recorded human history when the old and new worlds encountered each other in 1492, initiating the Columbian exchange. ${ }^{1}$ Over 500 years later, the Dominican Republic is again the locus of a global collision, the meeting of two seemingly disparate aspects of globalization: the international convergence of values ${ }^{2}$ regarding preservation of maritime heritage and the inexorable privatization of state responsibilities for managing it and other resources. ${ }^{3}$ These global trends have facilitated treasure hunters from more developed nations like the United States in convincing the Dominican Republic's resource managers to permit commercial salvage of Dominican submerged cultural patrimony in spite of the harmful environmental and long-term economic impacts, and in disregard of the Dominican government's conservationist laws and policies. ${ }^{4}$ Allowing such salvage is a departure from the international community's emerging practice of preservation of the Underwater Cultural Heritage

1. See generally Alfred W. Crosby, The Coltumbian exchange: Biological AND CUltural CONSEQUENCES OF 1492 (Praeger 2003) (1972) (chronicling the biological exchange between the Americas and Europe that began in 1492). See also C.R., When Did Globalisation Start?, THE ECONOMIST (Sept. 23, 2013, 9:00 AM), http://www.economist.com/ blogs/freeexchange/2013/09/economic-history-1 (positing that "[a]lthough Adam Smith himself never used the word, globalisation is a key theme in the Wealth of Nations[,]" and that Smith argued "the discovery of the Americas, by Christopher Columbus in 1492, accelerated the process of globalisation.").

2. See Alex Y. Seita, Globalization and the Convergence of Values, 30 CORNELL INT'L L.J. 429, 429 (1997) ("Globalization is causing, and being reinforced by, a worldwide convergence of economic and political values ....").

3. See generally, Alfred C. Aman, Jr., Globalization: Legal Aspects (Aug. 28, 2013) (unpublished manuscript) (on file with author) (examining the law's effect on the global environment).

4. Margaret E. Leshikar-Denton \& Pilar Luna Erreguerena, The Foundations of Underwater and Maritime Archaeology in Latin America and the Caribbean, in UNDERWATER AND MARITIME ARCHAEOLOGY IN LATIN AMERICA AND THE CARIBBEAN 25, 26 (Margaret E. Leshikar-Denton \& Pilar Luna Erreguerena, eds., 2008). See infra Part II, for a detailed explanation of Dominican cultural resource management laws. 
(UCH) as reflected in the international cooperation on protecting it through becoming a party to the 2001 United Nations Educational, Scientific and Cultural Organization (UNESCO) Convention for the Protection of the Underwater Cultural Heritage (2001 Convention), ${ }^{5}$ or using its Annex as a "best practices" guide. ${ }^{6}$ Furthermore, the trend in private international law toward recognizing the importance of conservation and preservation also calls into question the validity of continuing to engage in treasure hunting even under the auspices of traditional maritime salvage law. ${ }^{7}$

While there are both international agreements and domestic laws in place available to protect and preserve $\mathrm{UCH}$ off the coast of the Dominican Republic, the actual practice sees management responsibility being delegated to privately run treasure-hunting

5. See generally Convention for the Protection of the Underwater Cultural Heritage, Nov. 2, 2001, 41 I.L.M. 40 (2002) [hereinafter 2001 Convention]. This Note adopts the definition of Underwater Cultural Heritage from the 2001 Convention, as it represents the emerging international consensus on what is UCH: "all traces of human existence having a cultural, historical or archaeological character which have been . . . under water ... for at least 100 years ...." See id. at art. 1 . This could be a shipwreck, submerged city, or any other artifact or human remain found underwater. As most UCH at risk in Dominican waters are Spanish and other European Colonial shipwrecks or pre-Columbian artifacts, the controversy over an appropriate temporal cutoff (i.e., at what age does an artifact become "historical") is not at issue. However, in contrast to the 2001 Convention's definition, I address only culturally and historically significant $\mathrm{UCH}$ in recognition that the solution I propose (or any realistic solution) cannot possibly provide for management of all UCH, and must be limited to significant sites.

6. The Society for Historical Archaeology, the largest scholarly group concerned with the archaeology of the modern world (1400 AD-present), and the World Archaeological Congress (the only elected international body of practicing archaeologists) collectively represent the global professional archaeological community, and both support ratifying the 2001 Convention. MARGARET LESHIKAR-DENTON, 2012 YEAR-END REPORT OF THE SHA UNESCO COMMITTEE 1 (2012) (on file with author) ("The Committee supports the international ratification and implementation of the 2001 UNESCO Convention, and the adoption of its Annex as a 'best practices' document, even where ratification is unlikely; places emphasis on facilitating training opportunities and public awareness; facilitates NGO accreditation for SHA with the Meeting of States Parties; and monitors development of the Operational Guidelines."); see also Press Release, World Archaeological Cong., Underwater Cultural Heritage Convention Needs to be Implemented (July 14, 2008), available at http://www. worldarchaeologicalcongress.org/site/wacpress_20.php.

7. Even Professor David Bederman, a notable admiralty law scholar and proponent of using salvage law to manage $\mathrm{UCH}$, argues that "historic preservation values have been merged with "traditional' salvage law[,]" at least in the implementation of admiralty law in the U.S. court system. David J. Bederman, The UNESCO Draft Convention On Underwater Cultural Heritage: A Critique And Counter-Proposal, 30 J. MAR. L. \& CoM. 331, 345 (1999). See also Valentina Sara Vadi, Investing in Culture: Underwater Cultural Heritage and International Investment Law, 42 VAND. J. TRANSNAT'L L. 853, 867-69 (2009), for a detailed explanation of using private international law to manage UCH. 
companies for promises of short-term economic gain. ${ }^{8}$ This Note suggests that instead of succumbing to this harmful aspect of the global privatization and horizontal delegation trend, the Dominican government should respond to its administrative and financial challenges by authorizing a management framework that allocates responsibilities among domestic and foreign state and nonstate actors through a variant of Common-Pool Resource Management known as Living Museums in the Sea. This strategy is consistent with existing Dominican laws and the emerging international preservation consensus, and could also relieve the economic pressures that forced the Dominican government to privatize its $\mathrm{UCH}$ management in the first place. Furthermore, it provides the potential for larger, more equitable, and longer-lasting economic benefits than treasure hunting while also preserving the $\mathrm{UCH}$ for present and future generations.

\section{The Problem: Treasure Hunting of SubMerged ARtifacts Destroys CUltural PATRIMONY AND THE Fragile MaRINE ENVIRONMENT}

The ever-increasing pace of artifact discovery and the rapid degradation of the ocean environment necessitate disincentivizing developing countries like the Dominican Republic from selling or privatizing the management of their submerged cultural patrimonies. ${ }^{9}$ Treasure hunters prey on lesser-developed countries that permit

8. Peter Throckmorton, The World's Worst Investment: The Economics of Treasure Hunting with Real Life Comparisons, 1990 UNDERWATER ARCHAEOLOGY PROC. FROM SOC'Y FOR HIST. ARCHAEOLOGY CONF. 6, 7.

9. Although there is ongoing debate between the archaeological and commercial salvage (i.e., treasure hunter) camps about whether "commercial archaeology" (the excavation and sale of artifacts for profit) can be done in a way that preserves the historical and environmental integrity of the sites, I, in addition to many scholars, environmental and archaeological managers, and government officials, fundamentally disagree. See George F. Bass, After the Diving is Over, 1990 UnDERWATER ARCHAEOLOGY Proc. FROM SOC'Y FOR HIST. ARCHAEOLOGY CONF. 10, 10-12 (explaining that good archaeological technique does not equal good archaeology); see also George F. Bass, The Development of Maritime Archaeology, in THE OXFORD HANDBOOK OF MARITIME ARCHAEOLOGY 11-14 (Alexis Catsambis et al. eds., 2011) (explaining the fundamental incompatibility of archaeology and treasure hunting). Furthermore, I have a more fundamental problem with the for-profit excavation and sale of artifacts from an extremely fragile marine environment such as in the Dominican Republic. But see generally Underwater Cultural Heritage \& UNESCO in New Orleans: An Introduction, ODYSSEY PAPERS NO. 13 (Odyssey Marine Exploration), 2010, available at http://www. shipwreck.net/pdf/OMEPapers13-UNESCO.pdf, for the perspective of the commercial treasure salvage industry. This article does not take issue with cultural resource management firms, such as those organized under the American Cultural Resources Association (http://www.acra-crm.org), which have a long history of conducting competent and ethical excavation for profit, but only the commercial exploitation of artifacts. 
treasure hunting in a desperate attempt to exert some kind of control over the exploitation of their heritage. Treasure hunters "entice governments with promises of sure profits, but the overall result has been the destruction of LAC [Latin American and Caribbean] heritage sites and no sign of [long-term] financial reward for participating countries." 10 Not only do the proceeds from treasuring hunting fail to "provide vast sums to local coffers,"11 but this unscientific salvage of UCH also destroys what would otherwise be its sustainable value as an educational tool or tourist attraction. ${ }^{12}$ Artifacts have only one chance to be properly excavated, and following correct excavation protocol is impossible for companies beholden to shareholders and working toward a singular goal: recovering investments through the discovery of treasure. ${ }^{13}$ On top of this loss of cultural patrimony and historical data, the profit-driven treasure salvage industry inevitably causes the destruction of resources invaluable to the ecosystem around the shipwreck sites, harming threatened or endangered marine life dependent on these sites where shipwrecks have been integrated into the environment. ${ }^{14}$

10. Leshikar-Denton \& Erreguerena, supra note 4.

11. George F. Bass, Archaeology Versus Treasure Hunting, in ETHICAL Issues IN ARCHAEOLOGY 58, 58 (Larry J. Zimmerman, et al. eds., 2003).

12. See Importance of the Archaeological Record, NAUTICAL ARCHAEOLOGY PROGRAM AT TEX. A\&M UNIV., http://nautarch.tamu.edu/class/anth318/Class\%2003-\%20Importance\% 20of\%20Nautical\%20Archaeology.htm (last visited Nov. 17, 2013). See also generally NAT'L OCEANIC \& ATMOSPHERIC ASS'N, SUPPLEMENT TO FINAL REGULATORY FlEXIBILITY ANALYSIS FOR THE FINAL REGULATIONS IMPLEMENTING THE FINAL MANAGEMENT PLAN FOR THE Florida Keys National Marine Sanctuary: Commercial TREasure Salvors (1997), available at http://www.gc.noaa.gov/documents/060197_rfa_keys_salvors.pdf (providing a detailed economic impact analysis of the treasure salvage industry in Florida). The paper concludes that the treasure hunting enterprises are "high risk speculative" gambles in which few companies make a profit. Id. at 27 . It also states that in balance, the potential benefits to tourism from in situ preservation of submerged cultural resources outweighs the relatively minor economic impact on commercial treasure salvors resulting from sanctuary regulations. $I d$. at 84 .

13. See Beth Read, Open Season on Ancient Shipwrecks: Implications of the Treasure Salvors Decisions in the Fields of Archaeology, History, and Property Law, 4 NovA L.J. 213, 226-27 n.63 (1980) (emphasis omitted) (quoting D. Mathewson, Method and Theory of Marine Archaeology (1978) (unpublished thesis) (on file with Florida Atlantic University Library)), for an excerpt from D. Mathewson, an archaeologist who worked with treasure hunters, comparing archaeological excavations with salvage operations and concluding that "[r]esources for conducting archaeological research from within the salvage company had to be balanced against the priorities and expectations of the commercial operation. Under such a situation, it was impossible to develop a proper excavation program. ..."

14. OFFICE OF UNDERWATER SCI., IND. UNIV., INDIANA UNIVERSITY UNDERWATER ARChaEology TECHNIQUES TRAINING BOOKLET: METHODOlogy FOR INVESTIGating Submerged Cultural Resources and Associated Biodiversity 13, 45 (Charles D. 
Within the United States, a full spectrum of laws and management regimes preserves natural and cultural heritage through a number of strategies, including banning the application of the law of salvage and finds and contract salvage, prohibiting uncontrolled treasure hunting, and regulating commercial salvage or recovery in accordance with professional archaeological standards. ${ }^{15}$ As the laws and policies of the United States and other more developed nations severely restrict treasure hunting and make commercial salvage less profitable in those places, the lesser-developed countries become more viable alternatives. These countries therefore risk creating additional cultural and natural resource inequalities with the global "north" if they privatize already vulnerable regulatory institutions, ${ }^{16}$ much as they suffered tremendous income disparities at the turn of the twenty-first century due to the same phenomena. ${ }^{17}$ Yet, despite the considerable drawbacks of treasure hunting, the short-term financial incentives of being one of the few

Beeker \& Frederick H. Hanselmann eds., 2009) (establishing that shipwrecks are substrate for marine life, in particular coral); see also United States v. Fisher, $977 \mathrm{~F}$. Supp. 1193 (S.D. Fla. 1997) (enjoining treasure hunters from using destructive excavation technique involving blowing huge holes in the ocean floor in the Florida Keys National Marine Sanctuary, and holding them liable for several hundred thousand dollars for the damage and destruction of seagrass beds important to the coral reef ecosystem).

15. See, e.g., 2 U.S. DeP'T OF COMMERCE ET AL., Florida KEYs National Marine SANCTUARY, Final MaNagement Plan/EnVIRonMEnTal IMPACT STATEMENT 171 (1996), available at http://sanctuaries.noaa.gov/library/pdfs/fknms_fmpfeis_1996.pdf; NAT'L OCEANIC AND ATMOSPHERIC ADMIN., supra note 12, at 2.

16. Cf. Vadi, supra note 7 , at 898 . Vadi recommends using a form of privatized management of UCH called the "smart salvage" approach, which entails giving salvors the opportunity to cooperate in the management of $\mathrm{UCH}$ after its recovery and share subsequent revenues (from tourism or museum admissions) with the state for a period of time. I agree with her assertion that "states should not be considered owners but rather guardians or custodians of these cultural goods," and that her recommendations are an improvement over traditional salvage law, which rewards salvors for "rescuing" (i.e., looting) historic wrecks, often with "a generous percentage of the value of the salvaged vessel or part of the proceedings from the sale or auction of recovered treasures and artifacts." See id. at 867-69, 898 (explaining principles of salvage under maritime law). However, her recommendation perpetuates the unethical commercialization of artifacts by legitimizing profit-driven excavation activities. Mọreover, it is particularly inappropriate to the Dominican context due to pervasive corruption. See CARL MEACHAM, CTR. FOR STRATEgIC \& INT'L STUdies, The DOMINICAN REPUBliC: BECOMING A ONE-PARTy STATE? At VI (2013) ("The history of corruption and poor rule of law in the Dominican Republic is long-many even refer to a 'culture of corruption' that characterizes the country's political system. But however storied the country's experience with corruption may be, it cannot be denied that the problem has grown-and quickly-in recent years.").

17. See Nancy Birdsall, Carnegie Endowment for International Peace, Remarks at Overseas Development Council Conference, Making Globalization Work: Globalization and the Developing Countries: The Inequality Risk (Mar. 18, 1999), available at http://www.econ.yale.edu/alumni/reunion99/birdsall.htm. 
remaining treasure-hunter friendly regimes, ${ }^{18}$ combined with the lack of resources to manage its own submerged cultural heritage, compel the Dominican government to allow foreign treasure-hunting companies to contract out excavation on swaths of its coastline in return for a relatively paltry fee and a fifty-fifty split of the recovered artifacts. ${ }^{19}$ Nevertheless, this same government clearly recognizes the emerging international consensus around the treatment of UCH; in 2011, the Dominican Republic hosted a national consultation meeting for the 2001 Convention, a treaty that expressly prohibits the practice of uncontrolled treasure hunting. ${ }^{20}$

The Janus-faced nature of globalization-simultaneously causing increased privatization of government responsibilities and harmonization of values, in concert with the unique character of UCH as a cultural and often also natural resource 21 thus poses complex problems for conservationists, policymakers, and advocates for justice in developing countries. The challenge for any nation, particularly a lesserdeveloped one, is how to responsibly manage a resource that involves a multitude of local, national, and global stakeholders with limited human and financial resources and technical expertise. Even developed

18. See E-mail from Dick Borman, Manager of Los Cayos LLC, to unnamed members of Los Cayos LLC (Aug. 17, 2007, 22:53 MST) (on file with author) (expressing dismay over his company's recently cancelled contract with the Dominican government, as the Dominican Republic "is the only place in the world to look for sunken historical wrecks."). Los Cayos LLC is a now-defunct treasure hunting company that operated in the Dominican Republic.

19. See Charles D. Beeker, Living Museums in the Sea-Shipwrecks as Marine Protected Areas: A Personal Odyssey in Pursuit of Shipwreck Preservation, UNDERSEA J., Third Quarter 2010, at 47 (describing the typical treasure hunting contract made between foreign investors and the Dominican government, which calls for a fifty-fifty split between the parties).

20. National Consultation Meeting on Underwater Cultural Heritage in the Dominican Republic, 27-28 June 2011, UNESCO, http://www.lacult.org/proyectos/showitem.php? uid_ext=\&getipr=NjYuMjQ5Ljc1Ljkz\&lg=2\&id=110\&paginasweb=31\&idtitulo=1589 (last visited Nov. 9, 2013). However, under the express ban against applying the law of salvage and finds, there is an exception providing nations the authority to implement the 2001 Convention under maritime law provided the authorization is consistent with the Convention, including the Annex Rules. 2001 Convention, supra note 5, art. 4.

21. I refer to shipwrecks as a potential natural resource due to the fact that they often serve as de facto artificial reefs and support a localized ecosystem. See Why Preserve Shipwrecks, NAT'L PARK SERV., http://www.nps.gov/nr/travel/flshipwrecks/whypreserve.htm (last visited Oct. 5, 2014). Whether to characterize shipwrecks as a biological or natural resource in a legal sense and therefore open further avenues for states to exert jurisdiction over shipwrecks in their Exclusive Economic Zone is outside the scope of this Note. The appropriateness of doing so, at least under the United Nations Convention on the Law of the Sea, has been disputed in the literature. See, e.g., Bernard H. Oxman, Marine Archaeology and the International Law of the Sea, 12 COLUM.-VLA J.L. \& ARTS 353, 366 (1988). 
nations like the United States are having difficulty preserving, conserving, and curating their UCH. So, even if the Dominican government does retain ownership of all of its artifacts, how can it possibly conserve them indefinitely so that the artifacts retain their true value?22 Despite the development of public and private international law to preserve cultural heritage and the enactment of historic preservation laws by the Dominican government, some Dominican officials still offer short-term salvage agreements to private foreign companies that ruin any chance for longer-term economic benefits and result in privatization of public cultural patrimony. Given the obviously inequitable results of this iteration of the horizontal delegation of state power to private actors, what management framework can provide an alterative solution?

\section{ANALYTICAL STRUCTURE AND PROPOSED SOLUTION}

This Note responds to these questions through a three-part study of the Dominican situation that provides a new, globalized analysis to illustrate the appropriateness of a less state-centric and more community-based management solution. In Part I, I examine the global trends in UCH management law and policy to provide the context and rationalization for the contrasting situation in the Dominican Republic. Part II outlines the legal framework of UCH management in the Dominican Republic as a cautionary tale of privatization of public UCH management gone awry despite contrary national intentions. This second section will also engage with proponents of increased governmental control and the use of the limited sale of artifacts or other involvement of commercial treasure salvors as solutions to UCH management. In the final section, Part III, I propose a globalizationappropriate solution: Indiana University's Living Museums in the Sea (LMS) model. In doing so, I apply Elinor Ostrom's Common-Pool Resource Management theory, with Multilevel Environmental Governance power-sharing theory ${ }^{23}$ standing in for Ostrom's eighth factor, to the Dominican legal, cultural, and physical landscapes to

22. Michael Bawaya, Curation in Crisis, 317 SCIENCE 1025, 1025 (2007) (detailing the difficulties faced by U.S. collections managers in providing proper long-term care for artifacts). If U.S. archaeologists can barely keep up with the amount of artifacts being recovered, how can managers in developing countries be expected to properly preserve artifacts and thus ensure that they retain scientific value once they are removed from the water?

23. Multi-level governance theory echoes globalization theory's focus on the nation state's delegation of power to nonstate entities. See Katarina Eckerberg \& Marko Joas, Multi-Level Environmental Governance: A Concept Under Stress?, 9 Loc. ENV’T 405, 40607 (2004). 
analyze if, why, and how the LMS model can be successfully implemented in the Dominican Republic.

\section{The Global Trend in Underwater CUltural HERITAGE MANAGEMENT}

Contemporary UCH management is a transnational, globalized issue. Defined as "the process of denationalization of clusters of political, economic, and social activities" that "encompasses legal relationships involving domestic and international law as well as private ordering involving a host of nonstate actors who operate transnationally,"24 globalization and the emergence of transnational law have made progress protecting $\mathrm{UCH}$ under historic preservation laws in response to the use of private international law of salvage. Although the timehonored concepts of the commercial laws of salvage and finds are still employed by the treasure salvage industry to claim their booty under government authorization, ${ }^{25}$ the international community of states is gradually ${ }^{26}$ tacking toward a historic preservation regime that closely aligns to the professional archaeological community's ethics, including the uniform rejection of commercial exploitation. ${ }^{27}$

24. See Aman, supra note 3 , at 2 .

25. See, for example, Odyssey Marine Exploration, Inc. v. Unidentified Shipwrecked Vessel, 657 F.3d 1159, 1166 (11th Cir. 2011), for a recent, infamous case of a treasure hunting company staking an ultimately unsuccessful "possessory and ownership claim pursuant to the law of finds (Count One), as well as a salvage award claim pursuant to the law of salvage (Count Two)." See also Fathom Exploration, LLC v. Unidentified Shipwrecked Vessel or Vessels, 352 F. Supp. 2d 1218, 1220 (S.D. Ala. 2005), for an illustration of the process a treasure hunting company utilizes under the laws of salvage and finds to secure exclusive title to a wreck. The Court in this case also prevented the State of Alabama from dismissing the salvor's action due to the possibility that the wreck lay within state waters and was therefore state property under the Abandoned Shipwreck Act. The Court stated that " $[\mathrm{t}] \mathrm{o}$ bar a party from pursuing legal action to secure and maintain exclusive salvage rights on a shipwreck until such time as the party can precisely identify the wreck would do violence to time-honored admiralty principles relating to salvage." $I d$. at 1224 .

26. I use the term "gradually" because there are only forty-eight parties to the 2001 Convention, with Cambodia being the only Asian nation. See Convention on the Protection of the Underwater Cultural Heritage, UNESCO, http://www.unesco.org/eri/la/ convention.asp?KO=13520\&language=E\&order=alpha\#1 (last visited Dec. 20, 2013).

27. See Code of Conduct 1.2(e), Register of Professional ARChabologists, http://www.rpanet.org/displaycommon.cfm?an=1\&subarticlenbr=3 (last visited Oct. 17, 2013). The heritage of all mankind concept stems from "the Preamble to the 1954 Hague Convention for the Protection of Cultural Property in the Event of Armed Conflict, according to which damage to cultural property belonging to any people whatsoever means damage to the cultural heritage of all mankind, since each people makes its contribution to the culture of the world." Francesco Francioni, Public and Private in the International 
The global harmonization of laws at the domestic level is typically described as the phenomenon of states incorporating the legislation to implement treaties or conventions agreed to by nations under the auspices of international organizations. For example, states may implement domestic laws in agreement with the International Maritime Organization's uniform rules on safety in navigation and protecting the marine environment from international shipping, or the World Trade Organization's uniform rules on trade. ${ }^{28}$ The current situation of UCH management on a global scale illustrates this type of harmonization emanating from an agreement among nations on the minimum standards and requirements they will hold themselves and persons subject to their jurisdiction to through implementing domestic statutes and regulations.

\section{A. The 2001 UNESCO Convention on the Protection of the Underwater Cultural Heritage}

The United Nations' International Law Commission's first note of $\mathrm{UCH}$ is found in a 1956 preparatory report for the First United Nations Conference on the Law of the Sea (UNCLOS I), which noted that UCH was not a natural resource of the Continental Shelf and thus there were no rights of coastal state jurisdiction over $\mathrm{UCH}$ on the Continental Shelf. ${ }^{29}$ While the treatment of UCH was not addressed in any of the 1958 Conventions resulting from UNCLOS I, the issue was addressed in articles 149 and 303 of the 1982 United Nations Convention on the Law of the Sea (LOSC) that represented the culmination of UNCLOS III. ${ }^{30}$ The negotiators recognized that this framework did not adequately address the issue, evidenced by article 303(4)'s contemplation of a convention that would specifically address objects of a historical or archaeological interest found at sea. ${ }^{31}$ In 1987 , the commercial salvage of artifacts from the Titanic wreck site awakened the world to the fact

Protection of Global Cultural Goods, 23 EUR. J. INT'L L. 719, 719 (2012) (internal quotation marks omitted).

28. See Alfred C. Aman Jr., Globalization from the Ground Up: A Domestic Perspective, in 2 The Impact of GLOBalization IN THE UNiTED STATES 3, 9-11 (Beverley Crawford ed., 2008).

29. Sarah Dromgoole, Underwater Cultural heritage and international LaW 29-30 (2013) (citing Rep. of the Int'l Law Comm'n, 8th Sess., April 23-July 4, 1956, U.N. Doc. A/3159; GAOR, 11th Sess., Supp. No. 9 (1956)).

30. Ole Varmer, Closing the Gaps in the Law Protecting Underwater Cultural Heritage on the Outer Continental Shelf, 33 STAN. ENVTL. L.J. 251, 258-60 (2014) [hereinafter Closing the Gaps].

31. Id. at 262 . 
that all UCH was now accessible for commercial exploitation. ${ }^{32}$ The International Law Association's Committee on Cultural Heritage Law began drafting a convention to address UCH in $1988,{ }^{33}$ and UNESCO ${ }^{34}$ itself began officially addressing the matter in 1993 through a feasibility study for the creation of a UCH convention..$^{35}$ The study recognized that the existing international legal framework governing maritime activities through the LOSC was inadequate to protect $\mathrm{UCH}$ from looting and unregulated salvage. ${ }^{36}$ Furthermore, the study found that although an international instrument to protect $\mathrm{UCH}$ could be created, it would have to address jurisdiction of coastal states and how to control activities directed at UCH beyond coastal state jurisdictional limits under the LOSC; "the place of salvage law"; and which archaeological or professional standards to use as a benchmark for judging the appropriateness of activities directed at $\mathrm{UCH} .{ }^{37}$

The 2001 Convention $^{38}$ is thus the culmination of decades of contentious, yet ultimately fruitful, debate at the global level over the management of UCH. ${ }^{39}$ Under the 2001 Convention, States Parties agreed to take action to protect and preserve all $\mathrm{UCH},{ }^{40}$ stipulating that "in situ preservation shall be considered as the first option" for the

32. See Dromgoole, supra note 29 , at 48 .

33. Id. at 49-50 ("This draft ... was then forwarded to UNESCO for consideration and became the "blueprint for the development of the [2001 Convention]."' (quoting PATRICK J. O'KeEFe, SHIPWRECKED HERITAGE: A COMMENTARY ON THE UNESCO CONVENTION ON UNDERWATER CUltuRAL HERITAGE 23 (2002))).

34. Introducing UNESCO: What We Are, UNITED NATIONS EDUC., SCIENTIFIC, AND CULTURAL ORG., http://www.unesco.org/new/en/unesco/about-us/who-we-are/introducingunesco/ (last visited Nov. 9, 2013) ('UNESCO's mission is to contribute to the building of peace, the eradication of poverty, sustainable development and intercultural dialogue through education, the sciences, culture, communication and information.").

35. U.N. Educ., Scientific, and Cultural Org. Exec. Bd., Feasibility Study for the Drafting of a New Instrument for the Protection of Underwater Cultural Heritage, U.N. Doc. 146 EX/27 (Mar. 23, 1995) [hereinafter Feasibility Study]

36. See id. 141.

37. DROMGOOLE, supra note 29 , at 53.

38. See generally 2001 Convention, supra note 5.

39. See generally DROMGOOLE, supra note 29 , at 28-64, for a detailed discussion of the evolution of international law on underwater cultural heritage culminating in the 2001 Convention.

40. See 2001 Convention, supra note 5, art. 2 ("States Parties shall, individually or jointly as appropriate, take all appropriate measures in conformity with this Convention and with international law that are necessary to protect underwater cultural heritage, using for this purpose the best practicable means at their disposal and in accordance with their capabilities."); see also id. art. 7, 10, 12 (discussing treatment of UCH in internal waters, archipelagic waters and in the territorial sea; in the exclusive economic zone and on the continental shelf; and in the Area, respectively). 
treatment of $\mathrm{UCH}^{41}$ and explicitly rejecting the commercial exploitation of $\mathrm{UCH}^{42}$ Perhaps because of the existing international recognition of archaeological standards such as the International Council on Monuments and Sites (ICOMOS) Charter of 1996, the Annex to the Convention laying out the rules for activities directed at $\mathrm{UCH}$ has proven to be the instrument's most influential aspect. Not only has the academic archaeological community worldwide wholeheartedly adopted the Annex,43 "the Annex was unanimously adopted by all Member States, even by those countries which have no intention of ratifying the Convention." 44

Concededly, the 2001 Convention remains a controversial instrument to a few major maritime powers such as Russia, the United Kingdom, and the United States. ${ }^{45}$ It nonetheless must be recognized as

41. Id. Annex; see also About the Convention on the Protection of the Underwater Cultural Heritage, UNESCO, http://www.unesco.org/new/en/culture/themes/underwatercultural-heritage/2001-convention/ (last visited Oct. 17, 2013).

42. Id. art. 2 ("Underwater cultural heritage shall not be commercially exploited.").

43. See LESHIKAR-DENTON, supra note 6, at 1 ; see also Rules Concerning Activities Directed at Underwater Cultural Heritage, UNESCO, http://www.unesco.org/new/en/ culture/themes/underwater-cultural-heritage/2001-convention/annex-of-the-convention/ (last visited Nov. 21, 2014) ("The 36 Rules of the Annex present a directly applicable operation scheme for underwater interventions. Over the years, they have become a reference document in the field of underwater archaeology, setting out regulations for the responsible management of such cultural heritage.").

44. Ricardo L. Favis, Unit 1: The 2001 Convention on the Protection of the Underwater Cultural Heritage, in TRAINING MaNuAL FOR THE UNESCO FOUNDATION COURSE ON THE Protection aNd MaNagement of Underwater Cultural HeRitage in ASIA AND THE PACIFIC 2, 6 (Martijn R. Manders et al. eds., 2012); see also Vadi, supra note 7, at 865-66 ("[T]he Annex benefited from unanimous support at the time of its adoption. . . As the Annex is widely recognized as embodying professional norm guidelines, it might be replicated in national legislations without the need for ratifying the CPUCH.").

45. See Ole Varmer, Jefferson Gray \& David Alberg, United States: Responses to the 2001 UNESCO Convention on the Protection of the Underwater Cultural Heritage, 5 J. MAR. ARCHAEOLOGY 129, 131 (2010) (discussing U.S. support for most of the Convention and concerns or reservations about creeping jurisdiction and treatment of warships within territorial sea). However, France has become a party and Germany and the Netherlands are preparing to ratify the 2001 Convention. It therefore appears that the small number of major maritime powers that still have concerns is shrinking. See States Parties to the Convention of the Protection of the Underwater Cultural Heritage, UNESCO, http://whc.unesco.org/en/statesparties/ (last visited Dec. 14, 2013) (France, Italy, and Spain are maritime powers party to the convention). France ratified the convention in 2013, which a UNESCO press release stated "illustrates the growing support by large maritime powers for this instrument and for the protection of the submerged heritage." See France Ratifies the UNESCO 2001 Convention on the Protection of the Underwater Cultural Heritage, UNESCO (Feb. 8, 2013), http://www.unesco.org/new/en/media. services/single-view/news/france_ratifies_the_unesco_2001_convention_on_the_protection_ of_the_underwater_cultural_heritage/\#.UrXMLmRDvTk. See also Gonzalo Rodríguez Prado, Germany Prepares for the Ratification of the UNESCO Convention on the Protection 
the expression of a growing number of states of the importance of applying professional archaeological standards to $\mathrm{UCH}$, and has undoubtedly influenced how the parties to the 2001 Convention and even some other nations manage their UCH. ${ }^{46}$ Professors Toshiyuki Kono and Stefan Wrbka point to Italy as an example of a nation that expressly incorporated some of the protections of the 2001 Convention before it became a party to it.47 Moreover, the concerns of the major maritime powers (particularly the United States, the United Kingdom, and Russia) to the protections of UCH enshrined in the 2001 Convention have been limited to issues of so-called "creeping" coastal state jurisdiction and the treatment of sunken warships rather than to the actual concept of limiting the commercial exploitation of $\mathrm{UCH} .{ }^{48}$ The United States supports the overall goal and concept of protecting UCH by prohibiting its commercial exploitation, preferring in situ preservation and requiring that archaeological standards be applied when it is determined that recovery is necessary or appropriate. ${ }^{49}$ As

of the Underwater Cultural Heritage, UNITED NATIONS NIPPON FOUND. FELLOWSHIP ALUMNI. PARIS, 2ND NOVEMBER 2001 (Nov. 13, 2014), http://www.unfalumni.org/germanyprepares-for-the-ratification-of-the-unesco-convention-on-the-protection-of-the-

underwater-cultural-heritage-paris-2nd-november-2001/; Dalya Alberge, Britain Urged to Sign Up to Shipwreck Treaty to Protect Underwater Heritage, THE GUARDIAN (Mar. 22, 2014, 8:10 PM), http:/www.theguardian.com/uk-news/2014/mar/23/government-urgedsign-shipwreck-treaty ("Britain was initially supportive of the treaty during $2001 \mathrm{draft}$ negotiations, but abstained from voting fearing that it would not attract universal support. Since then, the report notes, several historically seafaring states that previously shared British concerns have now signed up. These include Spain, Portugal and France. The Netherlands, another key state, is now reconsidering its position, Cunliffe said. 'Germany is nearly there and Denmark is working on it fast. So we would be the only ones who hadn't."').

46. See Jean-Louis Luxen, Reflections on the Use of Heritage Charters and Conventions, THE GETTY CONSERVATION INST. (2004), http://www.getty.edu/conservation/ publications_resources/newsletters/19_2/feature.html ("With regard to practice, the norms expressed in charters and [UNESCO] conventions have had a positive effect all over the world. Their general message has been acknowledged, and recommendations have been widely followed. In nearly all countries, professionals have drawn up inventories of heritage, often accompanied by thematic reports and scientific publications. Official services have been established, creating a systematic policy on conservation and providing a framework for the management of sites. Despite divergences and errors, in general such practices seek to follow standards considered universal, as laid down in international texts.").

47. Toshiyuki Kono \& Stefan Wrbka, General Report, in THE IMPACT of UNIForm Laws on the Protection of Cultural Heritage and the Preservation of Cultural HERITAGE IN THE 21ST CENTURY 1, 199-200 (Toshiyuki Kono ed., 2010).

48. See Varmer, Gray \& Alberg, supra note 45.

49. See Statement of Robert C. Blumberg, U.S. Observer Delegate to the 31st UNESCO General Conference, to Commission IV of the General Conference, Regarding the U.S. Views on the UNESCO Convention on the Protection of Underwater Cultural Heritage 
such, the 2001 Convention should be viewed as a powerful normative and harmonizing force.

\section{B. Some Notable Domestic Laws and Private Party Protections for UCH}

The domestic legislation of nations host to significant UCH or treasure-hunting companies (or both), yet not party to the 2001 Convention, also evidences the materialization of an overall respect for the extra-monetary importance of UCH. Although home to the majority of treasure-hunting companies, ${ }^{50}$ protections for UCH within U.S. state and national territorial waters, and to some extent out onto the U.S. Outer Continental Shelf, ${ }^{51}$ are so restrictive that many would-be treasure hunters are deterred from operating in their home country. ${ }^{52}$ The U.S. government initially hindered-but did not strike a fatal blow-to the treasure-hunting industry with the 1987 Abandoned Shipwreck Act (ASA). ${ }^{53}$ The ASA was passed in light of mounting

(Oct. 29, 2001), available at http://www.gc.noaa.gov/documents/gcil_heritage2_blumberg.pdf; Statement of Ray Wanner, U.S. Observer Delegate to the 31st UNESCO General Conference Before the General Conference Plenary Regarding the U.S. Views on the UNESCO Convention on the Protection of Underwater Cultural Heritage (Nov. 2, 2001), available at $\mathrm{http}: / / \mathrm{www} . g c . n o a a . g o v / d o c u m e n t s / g c i l$ heritage2_wanner.pdf.

50. Craig Forrest, Historic Wreck Salvage: An International Perspective, 33 TUL. MAR. L.J. 347, 349 (2009) ("The U.S. treasure salvage industry is the largest, most technically advanced, and best funded in the world.").

51. See, e.g., National Marine Sanctuaries Act, 16 U.S.C. $§ 1431$ (2006) (authorizing the Secretary of Commerce to protect areas of the marine environment as officially designated marine sanctuaries due to their significant conservation, recreational, ecological, historical, scientific, cultural, archeological, educational, or esthetic qualities).

52. See Interview with Charles Beeker, Professor, Ind. Univ., in Santo Domingo, Dom. Rep. (Jan. 2011) ("Treasure wars in America are over, but places like the Dominican Republic where you can still do a 50-50 split with the government under Presidential Decree makes it one of the few remaining places in the world where treasure hunters can ply their trade."). Despite the suite of protective laws detailed in Part I.B, some states still grant treasure-hunting concessions. See, e.g., Underwater Archaeology Frequently Asked Questions, FLA. DEP'T STATE DIV. HISTORICAL RES., http://www.flheritage.com/ archaeology/underwater/faq.cfm\#22 (last visited Oct. 17, 2014) ("Some companies have applied for and received Exploration and Recovery Permits as administered by Rule 1A-31 of the Florida Administrative Code. The State of Florida will issue an Exploration or Recovery Permit after the applicant has met the stringent archaeological requirements."). For an example of a treasure hunting company that apparently has a concession from Florida, see QUEEN'S JEWELS LLC, http://www.1715treasurefleet.com/ (last visited Oct. 17, 2014) ("1715 Fleet - Queens Jewels, LLC is a group of Historic Shipwreck Salvors focused on the exploration and recovery of the famous 1715 Plate Fleet. We currently operate the largest permitted salvage operation in Florida waters.").

53. 43 U.S.C. $§ \S 2105-2106$ (2006). Treasure hunters with preexisting claims are not subject to the ASA. See 43 U.S.C. $\$ 2106$ (c) (2006) ("This chapter shall not affect any legal proceeding brought prior to April 28, 1988."). See also Closing the Gaps, supra note 30, at 
evidence that increasing numbers of people were not only visiting shipwrecks, but were also removing artifacts and thus irreparably damaging the archaeological record and causing the loss of U.S. and human history. ${ }^{54}$ Under the Act, the U.S. government asserted title to any abandoned shipwreck "(1) embedded in submerged lands of a State; (2) embedded in coralline formations protected by a State on submerged lands of a State; or (3) on submerged lands of a State and is included in or determined eligible for inclusion in the National Register," 55 then transferred title of said wrecks "to the State in or on whose submerged lands the shipwreck[s are] located." 56 It is important to note that although the text of the Act mandates that states "manage" shipwreck resources and develop protective policies with which to do so, the ASA also requires states to develop policies that "allow for appropriate public and private sector recovery of shipwrecks consistent with the protection of historical values and environmental integrity of the shipwrecks and the sites." 57 While commercial exploitation is in direct conflict with the 2001 Convention, the ASA provides for the participation of private commercial companies in protecting shipwrecks in a way that is consistent with the 2001 Convention, ${ }^{58}$ provided the company's activities are consistent with the Convention and its Annex Rules.

The Sunken Military Craft Act (SMCA) is another U.S. law that makes it difficult to treasure hunt in the United States and pushes U.S. treasure hunters to seek more favorable conditions in the lands and waters of lesser-developed nations.59 The SMCA was passed with the intent of "protect[ing] sunken military vessels and aircraft and the

273-76 (detailing some notable legal battles between treasure hunters and the states under the ASA).

54. See Protection of Historic Shipwrecks and the National Maritime Museum: Hearing Before the Subcomm. on Pub. Lands and Reserved Water, S. Energy and Natural Res. Comm., 98th Cong. 30 (1983).

55. 43 U.S.C. $\$ 2105$ (a) (2006).

56. $I d . \S 2105(\mathrm{c})$.

57. 43 U.S.C. $\$ 2103(\mathrm{a})(2)(\mathrm{c})$ (2006) (emphasis added).

58. See 2001 Convention, supra note 5, art. 4. Article 4 provides an exception to the general ban on the application of the law of salvage and finds for those nations wishing to use salvage law to implement the Convention. Additionally, when a nation joins the Convention, it has the discretion to exclude its application within territorial waters. See id. art. 29. Thus, if the United States were to join, it could exclude state lands and waters already subject to the ASA. Furthermore, unlike the ASA, the 2001 Convention "does not regulate the ownership of submerged historic remains." Frequently Asked Questions, UNESCO, $\quad$ http://www.unesco.org/new/en/culture/themes/underwater-culturalheritage/frequently-asked-questions/ (last visited Oct. 16, 2014). Ownership of property is handled so differently by different nations that providing for ownership of shipwrecks in the Convention would likely have made it impossible to reach a consensus.

59. Sunken Military Craft Act of 2004, 10 U.S.C. $\$ 113$ (2012). 
remains of their crews from unauthorized disturbance" wherever those vessels may lie. 60 Treasure hunters argue that the law's scope is too broad, as according to their understanding "ships in military service could mean anything from a World War II vessel carrying silver bars to a Spanish galleon returning from the New World with gold."61 As evidenced by the U.S. District Court for the Middle District of Florida and the Eleventh Circuit's classification of the silver- and gold-laden Spanish frigate Nuestra Señora de las Mercedes (sunk in 1804) as a naval vessel, it is clear that the treasure hunters' worst fears may have been realized. ${ }^{62}$ Whether the SMCA is actually so expansive may be further clarified in the implementing regulations, which have been proposed but not published in final version at the time of the writing of this Note. ${ }^{63}$

The U.S. judicial system, though traditionally a stalwart defender of individual property rights under the U.S. Constitution, has also shown remarkable concern for preserving the archaeological integrity of the UCH (particularly shipwrecks), even when state protections through the ASA or other federal cultural protection laws are not applicable. ${ }^{64}$ The company Sea Hunt brought an in rem action against two Spanish frigates-the Juno and La Galga-in order to solidify its salvage rights. Even though Sea Hunt obtained the proper permits from the State of Virginia ${ }^{65}$ (in whose waters the wrecks lay) to conduct salvage,

60. Protection for Sunken Military Vessels and Aircraft, NAvAL HIST. \& HERITAGE COMMAND, http://www.history.navy.mil/branches/org12-12.htm (last visited Oct. 6, 2014).

61. Vernon Silver, Treasure Hunters' Undersea Gold Rush Is Threatened by U.S. Navy, BLOOMBERG BUSINESSWEEK (May 5, 2014), http://www.businessweek.com/articles/201405-05/treasure-hunters-undersea-gold-rush-threatened-by-u-dot-s-dot-navy; see also Peter B. Campbell \& Rodrigo Pacheco-Ruiz, Treasure Hunting Is the World's Worst Investment, BLOOMBERGVIEW (May 7, 2014), http://www.bloombergview.com/articles/2014-05-07/ treasure-hunting-is-the-world-s-worst-investment (stating that "the U.S. Navy plans to redefine the Sunken Military Craft Act to include everything from historic galleons to Merchant Marine vessels from World War I and II").

62. Odyssey Marine Exploration, Inc. v. Unidentified, Shipwrecked Vessel, 675 F. Supp. 2d 1126, 1129 (M.D. Fla. 2009), aff'd, 657 F.3d 1159, 1175 (11th Cir. 2011).

63. Guidelines for Permitting Archaeological Investigations and Other Activities Directed at Sunken Military Craft and Terrestrial Military Craft Under the Jurisdiction of the Department of the Navy, 79 Fed. Reg. 620 (proposed Jan. 6, 2014) (to be codified at 32 C.F.R. pt. 767).

64. See, e.g., National Historic Preservation Act, 16 U.S.C. $\$ \S 470 \mathrm{a}-470 \mathrm{x}-6$ (2006); Native American Graves Protection and Repatriation Act, 25 U.S.C. $\$ \S 3001-3013$ (2006); Archaeological Resources Protection Act, 16 U.S.C. $\$ \$ 470 \mathrm{aa}-470 \mathrm{~mm}$ (2006).

65. Sea Hunt, Inc. v. Unidentified Shipwrecked Vessel or Vessels, 221 F.3d 634 (4th Cir. 2000). The State of Virginia argued that it owned the wrecks under the ASA and authorized the commercial salvage of the wrecks pursuant to a contract with a private for profit commercial salvor. Id. at 639. 
the Fourth Circuit held that Spain had not abandoned the shipwrecks, ${ }^{66}$ and that since they were still owned by Spain and subject to sovereign immunity, Spain had the right to deny any salvage or award.67 The court also pointed to Spain's "wishes to maintain [La Galga] as a sacred military gravesite" as reason why "a finding of implied abandonment would be improper." 68 As Virginia lacked the authority to issue a permit for salvage in the first place due to the finding of non-abandonment, Sea Hunt may be argued to be an admonition to the State of Virginia and other states that work with treasure hunters as well as to treasure hunters themselves. U.S. treasure-hunting companies also suffered notable setbacks after the extensive litigation surrounding the Titanic and Nuestra Señora de las Mercedes cases, even though these shipwrecks lay outside of U.S. territorial waters. 69

Professor James A. R. Nafziger asserts that the Titanic and Sea Hunt cases are evidence of the "development of a more cosmopolitan approach" that seeks "to apply the jus gentium and conventional international law more credibly and responsibly."70 National Oceanic and Atmospheric Administration International Section AttorneyAdvisor Ole Varmer added that "[e]ven judges sitting in Admiralty are recognizing the importance of international co-operation on the protection of UCH in accordance with the [Convention]," and asserted that although the United States is not a signatory to the Convention,

66. Id. at 647 .

67. Id. at $642-43$.

68. Id. at 647.

69. See Odyssey Marine Exploration, Inc. v. Unidentified, Shipwrecked Vessel, 675 F. Supp. 2d 1126, 1130 (M.D. Fla. 2009), aff'd, 657 F.3d 1159 (11th Cir. 2011) (ordering treasure hunting company to return artifacts including 594,000 silver and gold coins to Spain). See also R.M.S. Titanic, Inc., v. The Wrecked and Abandoned Vessel, its Engines, Tackle, Apparel, Appurtenances, Cargo, etc., 804 F. Supp. 2d 508, 509 (E.D. Va. 2011) (granting title to the Titanic artifacts to salvage company R.M.S. Titanic "subject to the covenants and conditions that the United States, through the United States Attorney, negotiated and finalized with RMST and the court[,]" which included having to keep the collection intact and available for public display and scientific research, rendering the artifacts essentially unsellable). While I interpret this outcome as a deterrent for other treasure hunting companies, RMS Titanic, Inc. has been able to monetize the Titanic artifacts through ticket sales to museum exhibits. RMS Titanic, Inc., PREMIER EXHIBITIONS, http://www.premierexhibitions.com/corporate/all/rms-titanic-inc (last visited Jan. 21, 2015).

70. See James A.R. Nafziger, United States, in THE IMPaCt OF UNIFORM LaWs on the Protection of Cultural Heritage and the Preservation of Cultural Heritage in THE 21ST CENTURY 757, 764 (Toshiyuki Kono ed., 2010) (explaining that there are three key features in the effort to develop of a more cosmopolitan approach: "to fashion a constructive in rem basis of adjudicatory jurisdiction; to apply the jus gentium and conventional international law more credibly and responsibly; and to redefine the general maritime law in terms of comparative insights and law-of-the-sea norms"). 
"most of the relevant [U.S.] federal agencies have indicated that they comply with the [2001 Convention] Rules in the Annex or comparable rules or guidelines." 71 When viewed as a collective body of law, the actions of the various entities making up the U.S. government evidence that "[a]lthough the United States [is] not [party] to the Convention, [it] compl[ies] with the terms of the Annex Rules and, therefore, ha[s] arguably accepted the terms of the Annex Rules as a matter of custom."72 Yet, as enlightened as these recent developments in U.S. jurisprudence may appear, they do not provide reliable protection to $\mathrm{UCH}$ outside of the United States, particularly for UCH located within the coastal state jurisdiction of nations in the global south that may ignore these precedents and apply their own laws. Notably, the Mercedes case involved claims of ownership and sovereign immunity by Spain, the complaints of Peru who also claimed ownership of the UCH, ${ }^{73}$ and the assertions of ownership by the salvor, all being appropriately dismissed by the Eleventh Circuit as a private salvor should not be able to put a U.S. Admiralty Judge in the position of resolving a dispute between Spain and Peru merely because the in rem action was filed in the United States. ${ }^{74}$ The lower court (whose decision was upheld by the Eleventh Circuit) correctly found that the dispute was more appropriately addressed in Spain because the Mercedes was a Spanish warship; ${ }^{75}$ ordered the return of all of the silver, gold, and other artifacts to Spain;76 and ultimately ordered the salvor to pay over $\$ 1,000,000$ of Spain's legal fees. ${ }^{77}$

The United Kingdom, Australia, and Norway (among others) have also extended protections to $\mathrm{UCH}$ within their maritime zones through domestic legislation in accordance with the emerging international norms without becoming party to the 2001 Convention. The United

71. Ole Varmer, United States: Responses to the 2001 UNESCO Convention on the Protection of the Underwater Cultural Heritage, in 21 JoINT NAUTICAL ARCHAEOLOGY POL'Y COMM. 61, 61 (2011).

72. Laura Gongaware, To Exhibit or not to Exhibit?: Establishing a Middle Ground for Commercially Exploited Underwater Cultural Heritage Under The 2001 UNESCO Convention, 37 TUL. MAR. L.J. 203, 206 (2012) (citing Interview with Ole Varmer, Att'yAdvisor, Nat'l Oceanic \& Atmospheric Admin., in D.C. (Aug. 5, 2011)).

73. See Amber Crossman Cheng, All in the Same Boat? Indigenous Property Rights in Underwater Cultural Heritage, 32 HouS. J. INT'L L. 695, 699-702 (2010), for a discussion of Peru's claims to the treasure and the property rights of indigenous peoples in UCH.

74. See 657 F.3d at 1171 ("If the res at issue is the property of a foreign state, the federal courts only have jurisdiction to arrest the res if authorized by the FSIA [Foreign Sovereign Immunities Act].").

75. Id. at 1166 .

76. 675 F. Supp. 2d 1126, 1130 (M.D. Fla. 2009).

77. Odyssey Marine Exploration, Inc. v. Unidentified Shipwrecked Vessel, 979 F. Supp. 2d 1270, 1283 (M.D. Fla. 2013). 
Kingdom's Protection of Wrecks Act of 1973 "provide[s] the country's initial authority for the protection of historic shipwrecks" and was expanded in 2002 with passage of the National Heritage Act to include "shipwrecks, aircraft, and other cultural resources."78 Although the United Kingdom did not adopt the 2001 Convention, it nonetheless stated in its explanation of its vote that " $[t]$ he procedures for the protection of underwater archaeology adopted in the Annex are those which are already followed by the United Kingdom with regard to the designation of wreck sites within [the UK's] territorial sea and internal waters."79 Australia "provides in the Historic Shipwrecks Act 1976 for a protective regime for all wrecks over 75 years old, which excludes the application of salvage law." 80 Norway amended its Law for the Protection of Cultural Heritage to include protection (and assert state ownership) of artifacts from shipwrecks after the discovery of the Akerendam treasure wreck in 1972.81

Tellingly, even the most vociferous critics of the 2001 Convention, such as Professor David Bederman-who called the draft Convention "a totally illogical and extreme reaction to the problems presented in historic shipwreck management and the conservation of the underwater cultural heritage,"82 recognize the importance of using proper archaeological techniques in excavating historic wrecks. ${ }^{83}$ As a clear sign of this harmonizing consensus in at least the Western world on the treatment of $\mathrm{UCH}$, major international treasure-hunting companies, which are the targets of this convention, take great pains to distance the characterization of their operations from the "smash and grab" reputation of their industry forbearers. ${ }^{84}$

78. Timothy Runyan, Management of Maritime Cultural Resources: An American Perspective, in THE OXFORD HANDBOOK OF MARITIME ARCHAEOLOGY, supra note 9, at 958.

79. Antony Firth, Underwater Cultural Heritage off England: Character and Significance, in 21 JOINT NAUTICAL ARCHAEOLOGY POL'Y COMM., supra note 71, at 15.

80. Forrest, supra note 50 , at 365 .

81. See Fredrik Søreide, Maritime Archaeology and Industry, in THE OXFORD HANDBOOK OF MARITIME ARCHAEOLOGY, supra note 9, at 1015-16. Søreide also states that "[m]ost European countries insist that underwater cultural heritage belongs to the state, with few rewards to the finder." Id. at 1014.

82. Bederman, supra note 7 , at 346 .

83. See id. at 352-353 (stating that salvors must undertake their task "in accordance with accepted contemporary archaeological recording standards").

84. See Ole Varmer, New International Law to Protect Underwater Cultural Heritage, 1 A.B.A. Sec. InT'L. L. ART \& Cultural Heritage L. NewSl. 1 (2008). 


\section{UCH MANAGEMENT IN THE DOMINICAN REPUBLIC: COMMAND, CONTROL, AND CASH IN}

As the current state of UCH management in the Dominican Republic illustrates, converging norms are not the only, nor even the dominant, attribute of the globalized world. The increasing importance of nonstate actors, which can "avoid political regulation and substitute themselves as new regulators of behavior" as well as attack "the monopoly of legitimate governance authority asserted through the state," has come to characterize the globalized present political reality even more than the emergence of a global consensus on governance. ${ }^{85}$ Moreover, when values converge among developed nations, this can further incentivize developing economies to deviate from the norm to create economic leveraging power. These dual pressures have played out in a particularly interesting way in the Dominican Republic, resulting in a complete misalignment of the country's officially stated goals and actual practice.

\section{A. A Brief History of Dominican Laws Regulating UCH}

From a purely legislative perspective, the Dominican Republic appears to have a strong, state-centric legal regime protecting its wealth of UCH that stretches back to the beginning of the last century. Decree No. 4347 of 1903 declared archaeological objects the property of the state and forbade their removal from the Dominican Republic. 86 Ironically, given the current state of affairs, the statement of purpose for this decree bemoaned the fact that so many artifacts had already been taken from the country to "enrich foreign museums." 87 The Commission for the Conservation of Monuments, Works, and Pieces of Historical, Artistic or Archaeological Importance was created in 1932 to nominate and take measures to protect these sites. ${ }^{88}$ Per the law, no one

85. See Larry Cata Backer, Private Actors and Public Governance Beyond the State: The Multinational Corporation, the Financial Stability Board, and the Global Governance Order, 18 IND. J. GLOBAL LEGAL STUD. 751, 754-56 (2011).

86. Decreto No. 4347 del 15 de diciembre de 1903, que declara propiedad del Estado los objetos arqueológicos [Decree Declaring Archaeological Objects to Be the Property of the State], G.O. No. 1522, del 26 de diciembre de 1903 (Dom. Rep.).

87. Id. (stating "que muchos ejemplares de esos restos preciosos han salido del país á aumentar la riqueza de Museos extranjeros") ["that many examples of precious remains have left the country to increase the richness of foreign Museums"] (author's translation).

88. Ley No. 293 del 13 de febrero de 1932, que crea una comisión de Conservación de Monumentos, obras y piezas de importancia histórica, artística o Arqueológica [Law Creating the Commission for the Conservation of Monuments, Works, and Pieces of 
could do anything to affect these sites without the permission of the commission, and no one could transport out of the country any of the nominated artifacts without the permission of Congress. ${ }^{89}$ The Dominican Archaeological Commission was created the following year, yet only given advisory powers. ${ }^{90}$ The next significant law relating to archaeology was passed as part of the sweeping Law No. 318 on the Cultural Heritage of the Nation during the repressive "Twelve Years" of President Joaquín Balaguer's autocratic rule.91 This law opened the door to the command, control, and cash in model in operation today. Law No. 318 forced owners of valuable cultural property (including artifacts) to declare them to the state; prohibited the removal of this property (even when it was private property) from the country except for limited exhibition and with governmental consent; and prohibited archaeological excavations (including in submerged sites) except with the permission of the State Secretariat for Education, Fine Art and Worship. ${ }^{92}$ However, this same secretariat could allow foreign "scientific bodies or institutions" and other qualified persons to excavate.93 Balaguer created the Office of Cultural Patrimony and gave it power over archaeological excavations (and essentially everything else detailed in the Law No. 318) the following year. ${ }^{94}$ Control of archaeology in the Dominican Republic changed hands once again in 1973, when Balaguer granted complete oversight of archaeological activities (including removal of artifacts from the country) to the Museum of the Dominican Man. ${ }^{95}$

Historical, Artistic or Archaeological Importance], art. 4, G.O. No. 4440, del 20 de febrero de 1932 (Dom. Rep.).

89. Id. arts. $3-5$.

90. Decreto No. 22, del 8 de septiembre de 1938, Creación de la Comisión Dominicana de Arqueología [Creation of the Dominican Commission of Archaeology], G.O. No. 5219, del 10 de septiembre de 1933 (Dom. Rep.).

91. See ana S. Q. Liberato, Joaquín Balaguer, Memory, and Diaspora: The Lasting Political Legacies of an American Protége 114 (2013) (describing the opposition party's denunciation of the "repression that plagued the Twelve Years" of Balaguer's authoritarian rule).

92. See Ley No. 318, sobre el Patrimonio Cultural de la Nación [Law on the Cultural Patrimony of the Nation], arts. 8, 10, 12, G.O. No. 9086, del 19 de junio de 1968 (Dom. Rep.).

93. Id. art. 12 (" $[\mathrm{L}]$ a Secretaría . . . podrán . . . autorizar dichas excavaciones . . . a los organismos e instituciones nacionales o extranjera de carácter científico, así como a personas físicas calificadas. ...") ("The Secretariat . . . will be able to . . . [provide] authoriz[ation] [of] said excavations ... to national and foreign bodies and institutions of a scientific character, as well as to qualified individuals.") (author's translation).

94. Reglamento No. 4195, sobre la Oficina de Patrimonio Cultural [Regulation on the Office of Cultural Patrimony], art. 2, G.O. No. 9159, del 15 de octubre de 1969 (Dom. Rep.).

95. Ley No. 564 del 27 de septiembre de 1973, para la Protección y Conservación de los Objetos Etnológicos y Arqueológicos Nacionales [Law for the Protection and Conservation 
The Dominican government did not specifically address UCH until 1979, when President Antonio Guzman issued Decree No. 683 to create an Underwater Archaeological Rescue Commission.96 Balaguer promulgated the internal rules for this Commission in 1987, including supervisory authority over archaeological "concessions," 97 the permitting regime under which treasure hunters still operate. Shortly thereafter (during the 1990s), treasure hunter Tracy Bowden acquired the rights to excavate the Nuestra Señora de la Concepción, one of the most productive wrecks (in terms of the monetary value of its recovered treasure) to be salvaged in the Dominican Republic. ${ }^{98}$ President Leonel Fernández further consolidated power over $\mathrm{UCH}$ with the creation of the National Office of Underwater Cultural Patrimony (ONPCS, but recently renamed the General Directorate of Underwater Cultural Patrimony, or DGPCS) in 1999, which oversees all treasure hunter permitting and the division of salvaged artifacts, and "replace[s] all previous authorities responsible for this patrimony."99 The DGPCS's implementing legislation notably references the ICOMOS Charter and the Dominican Republic's signing of the 1998 Santo Domingo Declaration on the protection of the $\mathrm{UCH}$, both precursor agreements to the 2001 Convention, and prohibits the commercialization of artifacts. ${ }^{100}$ Yet, despite the decree's language mandating protection of $\mathrm{UCH}$, buried in Articles five and six of Decree No. 289-99 is the power of the Office of

of National Ethnological and Archaeological Objects], G.O. No. 9315, del 8 de octubre de 1973 (Dom. Rep.).

96. Decreto No. 683, que crea e integra una Comisión Encargada del Programa de Rescate Arqueológico Submarino [Decree Creating and Integrating a Commission in Charge of the Underwater Archaeological Rescue Program], G.O. No. 9497, del 28 de febrero de 1979 (Dom. Rep.).

97. Decreto No. 310-87 del 17 de junio de 1987, Reglamento Interno de la Comisión Encargada del Programa de Rescate Arqueológico Submarino, art. Septimo [nternal Regulation for the Commission in charge of the Submarine Archaeological Rescue Program, art. 7] (Dom. Rep.).

98. Bowden was preceded by another American treasure hunter, Burt Webber, who recovered "a fortune" in 1978, and by New England sailor William Phips in 1687. See Centuries of Seeking, NAT'L GEOGRAPHIC, http:/www.nationalgeographic.com/features/98/ silverbank/t1.html\#cent (last visited Nov. 16, 2013) (outlining the history of treasure hunting related to the Concepción); see also NiCHOLAS J. SAUNDERS, THE PEOPLes of THE CARIBbean: AN Encyclopedia of ARCHAEOlogy and Traditional Culture 203 (2005) (estimating that the artifacts recovered from the Concepcion are worth some $\$ 10$ million).

99. Margaret Leshikar-Denton, Caribbean Maritime Archaeology, in THE OXFORD HANDBOOK OF MARITIME ARCHAEOLOGY, supra note 9, at 643. See Decreto No. 289-99, que crea la Oficina Nacional de Patrimonio Cultural Subacuático [Decree Creating the National Office of Underwater Cultural Patrimony], art. 3, G.O. No. 10019, del 30 de junio de 1999 (Duin. Rep.) [hereinafter Decree No. 289-99].

100. Set Decreto No. 289-99, supra note 99, at introduction; see also Leshikar-Denton \& Erreguerena, supra note 4, at 29. 
Underwater Cultural Patrimony to grant third-party concessions to assist with its mission. ${ }^{101}$ Treasure hunters have been successful in obtaining contracts for commercial salvage that appear to go well beyond the intent of this provision to provide the Dominican government some discretion in working with the private sector. These contracts instead result in the exploitation of $\mathrm{UCH}$ that circumvents the underlying purpose of the Act. ${ }^{102}$

In addition to its domestic legislation, the Dominican government has also consistently tried to portray itself as a team player on international cultural protection issues and officially concurs with the mainstream international consensus on the protection of artifacts. It adheres to both Hague Conventions for the Protection of Cultural Property in the Event of Armed Conflict and the UNESCO Convention on the Protection of the World Cultural and Natural Heritage, and it approved and ratified the 1970 UNESCO Convention on the Means of Prohibiting and Preventing the Illicit Import, Export and Transfer of Ownership of Cultural Property. ${ }^{103}$ The Dominican Republic was also elected to UNESCO's executive board in November 2013.104

Despite these internationalist overtures, the Dominican Republic's most recent move to exert more control over its $\mathrm{UCH}$ came in the form of the 2007 passage of Act No. 66/07, in which the Dominican Republic declared itself an archipelagic state, expanded its territorial sea from six to twelve nautical miles $(\mathrm{nm})$, and proclaimed a twenty-four $\mathrm{nm}$

101. Decreto No. 289-99, supra note 99, at art. 5-6 (stating that the powers of the Office include the following: "execute its program of study, salvage, conservation, and enhancement of artifacts through third-party concessions") (author's translation).

102. See id. art. 2(b) (describing that the law intended to ban searches aimed solely at treasure hunting: "Search, investigation and intervention of this heritage should be performed only by specialists with scientific objectives and through programs of mutual cooperation among States, excluding all intervention of a purely pecuniary or commercial nature.") (author's translation).

103. See Protocol to the Convention for the Protection of Cultural Property in the Event of Armed Conflict, The Hague, 14 May 1954, UNESCO, http://www.unesco.org/eri/lal convention.asp?KO=15391\&language $=\mathrm{E}$ (last visited Dec. 14, 2013); see also Second Protocol to the Hague Convention of 1954 for the Protection of Cultural Property in the Event of Armed Conflict, The Hague 26 March 1999, UNESCO, http://www.unesco.org/ eri/la/convention.asp?KO=15207\&language $=\mathrm{E}$ (last visited Dec. 14, 2013), States Parties to the World Heritage Convention, UNESCO, http://whc.unesco.org/en/statesparties/ (last visited Dec. 14, 2013), and Convention on the Means of Prohibiting and Preventing the Ilicit Import, Export and Transfer of Ownership of Cultural Property, Paris 14 November 1970, UNESCO, http $/ /$ www.unesco.org/erila/convention.asp?KO=13039\&language=E\&order=alpha (last visited Dec. 14, 2013).

104. See Executive Board: Results of Elections, UNESCO, http://www.unesco.org/new/en/ general-conference-37th/elections/results-executive-board/ (last visited Dec. 19, 2013). 
contiguous zone and a $200 \mathrm{~nm}$ Exclusive Economic Zone (EEZ). ${ }^{105}$ Article 16 of the Act specifically addresses $\mathrm{UCH}$, both establishing a statutory body known as the National Maritime Authority "whose main function is to oversee the research, conservation, and exploitation of living and nonliving resources of the sea, seabed, and subsoil," and declaring as a national priority the preparation of "a register of the living and non-living, renewable and non-renewable resources of the superjacent waters, seabed and subsoil in the exclusive economic zone, as well as salvage operations with respect to treasures from ancient sunken vessels within the exclusive economic zone which constitute part of the national cultural heritage." 106 The United States and the United Kingdom took issue with the Act, questioning whether the Dominican Republic satisfied the requirements under the LOSC for being an archipelagic state and noting that "the paragraph following article 14 appears to claim rights to old shipwrecked vessels in its claimed EEZ, rights which are not accorded to coastal States in Part V of the [LOSC] Convention."107 The U.S. government further responded to Act No. 66/07 with a study that appears to criticize the Dominican Republic's efforts to assert jurisdiction over the salvage of UCH in the Dominican EEZ, stating " $t]$ o the extent that the Dominican Republic is relying on coastal State jurisdiction to implement this provision [regarding salvage operations], Article 303.2 [of the LOSC] limits coastal State jurisdiction over such objects to the seaward limit of the coastal State's 24-nm contiguous zone."108

Interestingly, the National Maritime Authority established under Act No. 66/07 includes a representative of the State Secretary for the Environmental and Natural Resources, but no one from the Ministry of Culture or Monuments, in stark contrast to the UCH management regime of previous decades. ${ }^{109}$ Since the passage of Law No. 41-00 in 2000, the DGPCS (and therefore jurisdiction over UCH) was placed

105. U.N. Div. for Ocean Affairs and the Law of the Sea, 65 Law of the Sea Bulletin, at 18-21 (2007) [hereinafter Bulletin 65]; U.N. Div. for Ocean Affairs and the Law of the Sea, Act. No. 573 of 1 April 1977: Amending Act. No. 186 of 13 September 1967 on the Territorial Sea, Contiguous Zone, Exclusive Economic Zone and Continental Shelf, Art. 1 (establishing $6 \mathrm{~nm}$ territorial sea).

106. Bulletin 65 , supra note 105 at 30 .

107. U.N. Div. for Ocean Affairs and the Law of the Sea, 66 Law of the Sea Bulletin, at 98-99 (2008) [hereinafter Bulletin 66] (includes a joint démarche undertaken by the United Kingdom of Great Britain and Northern Ireland and the United States of America in relation to the law of the DR No. 66-07 of 22 May 2007, Oct. 18, 2007).

108. U.S. DEP'T OF STATE, BUREAU OF OCEANS AND INT'L ENVTl. AND SCIENTIFIC

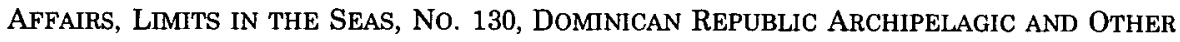
MARITIME CLAIMS AND BOUNDARIES (2014), available at http://www.state.gov/documents/ organization/221366.pdf.

109. Bulletin 65 , supra note 105 at 31 . 
squarely under the control of the Secretary of State of Culture, so it is noteworthy that the Dominican government would create a new oversight body for historic wreck salvage. ${ }^{110}$ Although this archipelagic legislation may signal a shift in how the Dominican government seeks to assert jurisdiction over its $\mathrm{UCH}-$ as a natural as well as a cultural resource, or as a proxy for claiming other seabed resources or expanded maritime territory111 - the DGPCS (still under the control of the Ministry of Culture) continues to be the permit-issuing entity for the time being. ${ }^{112}$

Scholar Sophia Kopela argues that the Dominican government's archipelagic expansion, combined with the Decree No. 289-99 grant of authority to the DGPCS over all research and excavation taking place in all maritime zones claimed by the Dominican Republic, is evidence of an emerging trend in international law for states dissatisfied with the "inadequacy of [the] provisions for the protection and preservation of UCH" in the LOSC to take matters into their own hands. ${ }^{113}$ Although Kopela is correct that the Dominican government is attempting to solidify its control of this and other incredibly valuable marine resources (such as seabed oil and gas) "in line with an emerging practice in [customary] international law concerning the exercise of jurisdiction over archaeological and historical objects found on the CS [Continental Shelf] and in the EEZ,"114 this is not convincing evidence that the Dominican Republic will soon ratify the 2001 Convention. ${ }^{115}$ The 2001 Convention provides that it will be implemented consistently with the LOSC-so the assertion of coastal state jurisdiction under the 2001 Convention is still limited to twenty-four $\mathrm{nm}$. Jurisdiction beyond that in the EEZ and on the Continental Shelf would be based on the consent

110. Ley No. 41-00, que crea la Secretaría de Estado de Cultura [Law Creating the Secretary of State for Culture], art. 1, G.O. No. 10050, del 5 de julio del 2000 (Dom. Rep.).

111. China has recently begun enforcing its claims to shipwrecks in the South China Sea, perhaps as part of an attempt to claim strategic areas "which it says has been part of its territorial waters for centuries." See Jeremy Page, Chinese Territorial Strife Hits Archaeology, WALL ST. J. (Dec. 2, 2013), http://online.wsj.com/news/articles/ SB10001424052702304470504579164873258159410.

112. See Divers Find Unexpected Treasures Among Coins in Shipwreck off Dominican Republic, REUTERS (Sept. 12, 2013), http://www.reuters.com/article/2013/09/12/ globalmarine-treasure-idUSnPNFL79114+1e0+PRN20130912 ("Divers from Anchor Research and Salvage (a Global Marine Exploration, Inc. company) working with the Punta Cana Foundation painstakingly excavated the wreck site under contract with the Underwater Cultural Heritage division [DGPCS] of the Dominican Minister of Culture.").

113. Sophia Kopela, 2007 Archipelagic Legislation of the Dominican Republic: An Assessment, 24 INT'L J. MARINE \& COASTAL L. 501, 530 (2009).

114. Id. at 533 .

115. See id. at $531 \mathrm{n} .130$ ("It is expected that the DR will very soon ratify the CPUCH [2001 UNESCO Convention]"). 
or agreement between parties and would therefore not provide a basis for enforcement against foreign flagged vessels and nationals not parties to the 2001 Convention. ${ }^{116}$ Instead, the archipelagic claim and corresponding expansion of maritime zones should be viewed as a way to gain or solidify jurisdiction and control over activities directed at seabed resources (including $\mathrm{UCH}$ ) that may interfere with or trigger coastal state jurisdiction over natural resources. While there is no indication that the Dominican Republic's action involves assertion of rights of ownership or lack of respect for the foreign sovereign immunity of other countries-such as Spain, who was the original owner of many of these wrecks and may still own them if not abandoned-the law does not seem to be a precursor to signing an agreement (i.e., the 2001 Convention) that would require the Dominican Republic to consult with other nations that may have an interest, including the wreck's original owner.117 That being said, Dominican politics are notoriously unpredictable, and a future Dominican administration could decide that becoming a State Party to the 2001 Convention would further its goals. ${ }^{118}$ Nevertheless, even if the Dominican Republic did accept or ratify the 2001 Convention, its government (and people) would still face the same temptation, due to lack of funding and infrastructure, to give concessions to treasure hunters under the guise of outsourcing management.

116. 2001 Convention, supra note 5, art. 3. Additionally, the 2001 Convention's provisions on how parties cooperate to protect $\mathrm{UCH}$ on the CS are not an extension of coastal state jurisdiction over $\mathrm{UCH}$, but rather an agreement between parties on how to cooperate in the protection of $\mathrm{UCH}$ in that area: a coastal state may take the lead on protecting $\mathrm{UCH}$ recognizing that when the flag state of the $\mathrm{UCH}$ is determined, it may take over the lead. See id., art. 10(3)(b).

117. See id., art. 10 ("Where there is a discovery of underwater cultural heritage or it is intended that activity shall be directed at underwater cultural heritage in a State Party's exclusive economic zone or on its continental shelf, that State Party shall: (a) consult all other States Parties which have declared an interest under Article 9, paragraph 5, on how best to protect the underwater cultural heritage[ ]"). However, all nations already have a duty to protect UCH and cooperate with each other for that purpose under Art 303(1) of the LOSC, so it may be argued that nations party to the LOSC already have a duty to consult with the flag state of the vessel as well as owner of cargo and others with an interest.

118. See AMB Country Risk Report Dominican Republic, A.M. BEST, 1, 4 (Aug. 18, 2014), http://www3.ambest.com/ratings/cr/reports/dominicanrepublic.pdf. My personal experience with the unpredictability of the Dominican political system is derived from the over two years I lived and worked there as a U.S. Peace Corps Volunteer. 


\section{B. A Critique of Increasing State Ownership of UCH and Funding Its Management Through the Sale of Artifacts in the Dominican Republic}

As evidenced by its suite of laws and international agreements, the Dominican government appears to be rigidly controlling its UCH and harmonizing its treatment of cultural property with international norms. However, the actual excavation and disposition of the artifacts evidences the denationalizing effects of globalization. Similar to resource extraction and manufacturing, the increasingly strict regulations on the exploitation of UCH in the developed world have pushed treasure hunters to certain areas of the global south that are both rich in maritime history and host to amenable regimes. ${ }^{119} \mathrm{~A}$ quick Internet search can provide anyone with a little cash and a desire to own a piece of history with the opportunity to not only buy artifacts from Dominican waters, but also to invest in a treasure-hunting expedition. ${ }^{120} \mathrm{~A}$ large portion of the one-quarter division of the artifacts given by the Dominican government to the treasure-hunting company Anchor Research \& Salvage from the Pewter Wreck, a 450-year-old Spanish merchant vessel that sank near Punta Cana off the eastern shore of the Dominican Republic, was sold at auction in the United Kingdom on November 24, 2013.121 The Dominican government is clearly allowing foreign treasure hunters to exploit the loopholes in its protective regime; however, this is more of an attempt to have at least some control over the disposition of its heritage rather than evidence of outright avarice. In leasing out segments of its coastline to treasurehunting companies, the DGPCS has implemented an unsustainable type of Individual Transferrable Quota as a last-ditch effort to manage its $\mathrm{UCH} .{ }^{122}$

119. See generally UNDERWATER AND MARITIME ARCHAEOLOGY IN LATIN AMERICA AND THE CARIBBEAN, supra note 4 (noting that many countries in the global south have yet to ratify the 2001 Convention and have not implemented legislation of their own to protect $\mathrm{UCH}$ ).

120. See, e.g., Next-Generation Treasure Hunters: Global Marine Exploration, Inc. Seeks $\$ 12$ Million Dollar Investment in Emerging Deep Diver Technology, PR NEwSWIRE (Oct. 3, 2013), http://www.prnewswire.com/news-releases/next-generation-treasure-hunters-globalmarine-exploration-inc-seeks-12-million-dollar-investment-in-emerging-deep-divertechnology-226342021.html.

121. See Pewter Recovered by GME to be Auctioned in United Kingdom, GLOBAL MARINE EXPLORATION (Nov. 12, 2013), http://gmexploration.com/pewter-recovered-by-gme-to-beauctioned-in-united-kingdom/; see also Hannah Osborne, Punta Cana Pewter Treasure from Dominican Republic Wreck for Auction, InTERNATIONAL Business Times (Nov. 4, 2013, 2:24 PM), http://www.ibtimes.co.uk/punta-cana-pewter-wreck-dominican-republicshipwreck-519437.

122. See Mairobi Herrera, Una "Mina de Oro" en el Fondo Del Mar, Listin DiaRio, (Jan. 9, 2012), http://www.listindiario.com.do/la-republica/2012/1/8/217427/Tesoros-marinos-de- 
The Dominican situation-an official policy of centralized state power with relative anarchy roiling underneath-demonstrates that strategies recommending the funding of $\mathrm{UCH}$ management in developing countries through revenue sharing with salvors ${ }^{123}$ or the sale of artifacts deemed archaeologically unimportant ${ }^{124}$ perpetuate the problem. Even though treasure hunters are only permitted to excavate in their respective concessions, the Dominican government is notoriously either unable or unwilling to regulate on-the-ground activity, even within officially protected areas. ${ }^{125}$ Treasure hunters have even used explosives to recover artifacts in the Dominican Republic's Silver Banks humpback whale sanctuary, the sister sanctuary to the U.S. Stellwagen Bank National Marine Sanctuary. ${ }^{126}$ Furthermore, unfettered state ownership of UCH (as opposed to stewardship, which would not include the right to sell) can be actively destructive in a

RD-atraen-a-cinco-empresas (Naming the four treasure hunting companies with excavation concessions in the Dominican Republic: Caribe Salvage S.A. run by legendary treasure hunter Tracy Bowden, Fundación Punta Cana of Paul Beswick, Anchor Research \& Savalge, S.R.L. of Bobby Prichert, and Deep Blue Marine of Wilfred Blum. Indiana University is incorrectly listed as having a commercial excavation concession, but does conduct non-commercial archaeological research under agreement with the DGPCS. (See Interview with Matthew Maus, Research Coordinator, Indiana University Office of Underwater Science, in Bloomington, Ind. (Dec. 21, 2013))). Individual Transferrable Quotas (ITQs) are usually used to manage renewable natural resources such as fish in areas without clear boundaries: they allow the owner of the ITQ to catch a portion of a total allowable catch (TAC) each season. The quantity of the ITQs "change proportionately to changes in the TAC set for a species each season. ITQs are fully tradeable and can be sold or leased to other persons." See Glossary of Terms, AUSTRALIAN FISHERIES MGMT. AUTH., http://www.afma.gov.au/resource-centre/teachers-and-students/glossary-of-terms/ (last visited Dec. 21, 2013). As shipwrecks are obviously unrenewable, even the bestmanaged ITQ system is inherently destructive to the archaeological record.

123. See Vadi, supra note 7 , at 899 .

124. See Daniel De Narvaez, The UNESCO Convention for Protecting Underwater Cultural Heritage: A Colombian Perspective, in ODYSSEY PAPERS No. 13, supra note 9, at 26 (endorsing the sale of artifacts "of no cultural or archeological significance" to pay for $\mathrm{UCH}$ management in Colombia).

125. See George Holmes, The Rich, the Powerful and the Endangered: Conservation Elites, Networks and the Dominican Republic, 42 ANTIPODE 624, 638 (2010) (explaining that the Dominican Republic has many "paper parks," defined as "protected areas that exist in law but which have very little protection in reality[.]").

126. See Interview with Charles Beeker, Professor, Indiana University, in Bloomington, Ind. (Dec. 10, 2013) (on file with author), for Beeker's statement that he confirmed with employees of the DGPCS that ceramics from the wreck of the Nuestra Señora de la Concepción (located in the Silver Banks sanctuary) exhibit fresh breaks from the use of explosives for artifact recovery. See also Memorandum of Understanding Between the United States National Ocean Service and the Santuario de los Mamíferos Marinos of the Dominican Republic to Collaborate on International Protection of the Humpback Whale, U.S.-Dom. Rep., NOS Agreement Code: MOA-2006-068/7297, Dec. 4-8, 2006, available at http://stellwagen.noaa.gov/sister/pdfs/dr_mou.pdf. 
country with pervasive government corruption like the Dominican Republic. ${ }^{127}$ Even if artifacts were sold after only the most exhaustive, academically rigorous, and environmentally responsible excavation, there is little chance that the money from that sale would benefit either the community abutting the waters from where the artifact was taken, or even the Dominican State as a whole.

This proliferation of the consolidation of state power over UCH combined with outsourcing to commercial salvors is disastrous for developing nations, not only because of the irretrievable loss of cultural and historical data, but also because of the ensuing environmental and economic destruction. Historic shipwrecks-particularly wrecks in shallow, warm water-provide excellent substrate for critically threatened coral reefs. ${ }^{128}$ This is yet another example of how commercial exploitation of UCH through salvage-based companies is a poor solution for the Dominican cultural patrimony. Contrary to Vadi's, Bederman's, and the Odyssey team's assertions, historic shipwrecks are usually not in environmental marine peril and thus needing "rescue" to protect the wreck's educational value. ${ }^{129}$ Shipwrecks stabilize over time, slowly becoming incorporated into the seabed and covered in a protective layer of hard material and marine life through a process known as concretion. ${ }^{130}$ Excavating shipwrecks almost inevitably causes the destruction of biological resources and should therefore be undertaken only when excavation is absolutely necessary to extract knowledge from or protect the wreck, and only by parties that have the time and expertise to mitigate these harms. ${ }^{131}$

Furthermore, the loss of environmental resources inevitably causes the loss of economic resources in the Caribbean context. Underwater archaeology pioneer Peter Throckmorton warned over a decade ago that "American treasure hunting is destroying scant resources of desperately

127. See MEACHAM, supra note 16.

128. Hans K. Van Tilburg, Dept. of Defense Legacy Resource Management Program, U.S. NAVY ShIPWRECKS IN HaWaIIAN Waters: AN INVENToRy of SubMerged NAVAL PROPERTIES 11 (2003) ("Warm clear waters also encourage coral growth, and hard substrates like shipwreck sites make excellent substrates for colonization. In waters shallower than 60 feet, coral growth can completely obscure artificial objects.").

129. See Vadi, supra note 7, at 898 (stating erroneously the belief shipwrecks are at risk of destruction by tides; however, her assertion that human activities pose a great threat to $\mathrm{UCH}$ is unequivocally correct).

130. See Indiana UnIVERSiTy UNDERWATER ARChaEology Techniques Training BOOKLET, supra note 14, at 21-22 (illustrating how wrecks become stabilized due to incorporation into the seabed over time); see also id. at 29 (defining concretion as "a composite crust of marine minerals, corrosion products, sediments, and natural life that eventually coats the most metal artifacts and some organic items deposited in the sea").

131. See generally supra note 9 (arguing that commercial salvors cannot give this level of care due to the financial pressures of their economic model). 
poor emerging Caribbean nations."132 Throckmorton stated that with the decline of agricultural and other resource exports from the Caribbean, "tourism is rapidly becoming the treasure of the Caribbean," and treasure hunting robs these developing countries of that opportunity. ${ }^{133}$ Moreover, the sun-and-sand tourism that has long dominated the Dominican economy, requiring intensive coastal development and causing tremendous environmental degradation, cannot guarantee indefinite profit any more than the one-shot sale of an artifact. 134

Treasure-hunting companies are not unresponsive to these criticisms, and are very aware that they operate in the Dominican Republic only at the pleasure of the Dominican government. Similar to alleged greenwashing by various multinational energy companies, some treasure-hunting companies seem to have been influenced by growing global concern over cultural heritage and have gone to great lengths to sanitize their images. Anchor Research \& Salvage, the company permitted to work the Pewter Wreck, has partnered with the Punta Cana Foundation, ${ }^{135}$ which-ironically-also funds coral reef conservation efforts in partnership with the University of Miami.136 Since treasure-hunting companies at least seem to fear the conservationist leanings of the Dominican government, there is hope that the Dominican Republic could be open to a different model, provided that another nonstate (i.e., something the Dominican government would not have to pay for) actor could fill the treasure hunter's role in the Dominican UCH management scheme. Clearly, due to the overwhelming pressure on poorer countries to capitalize on their resources as expeditiously as possible, another method that allows

132. Throckmorton, supra note 8 , at 7 .

133. Id. As Throckmorton notes, buying into treasure hunting is not only unethical for the harm that it does to developing nations, it is also an incredibly stupid investment that borders on fraud. See id. at 10. For example, Wilfred Blum of Deep Blue Marine, one of the treasure hunting companies authorized to work in the Dominican Republic as of January 2012, was sanctioned and "unconditionally and permanently prohibited from serving or acting ... [in any capacity] for, a registered investment company ..." for violations of the Securities and Exchange and Investment Company Acts in November, 2012. Wilfred R. Blum, Exchange Act Release No. 68258, Admin. Proceeding File No. 3-14961 (Nov. 19, 2012) (default order).

134. See Colin Crawford, Protecting Environmentally.Sensitive Areas and Promoting Tourism in "The Back Patio of the United States:" Thoughts About Shared Responsibilities in Ecosystem and Biodiversity Protection, 25 UCLA J. ENVTL. L. \& POL'Y 41, 53-54 (20062007).

135. See Divers Find Unexpected Treasures Among Coins in Shipwreck off Dominican Republic, supra note 112 .

136. See Coral Gardens, PunTaCana EcologiCal Found., http://www.puntacana.org/ coral/index.html (last visited Dec. 20, 2013). 
developing states to sustainably utilize these resources with little of their own financial input must be developed.

\section{Profit Without Plunder? A Globalized Yet Community-BASED MANAGEMENT STRATEGY AS A BEACON OF HOPE IN THE SCHOLARSHIP V. SALVAGE STORM}

The ongoing exploitation of UCH in developing countries like the Dominican Republic that profess their intent to protect it, and the obvious problems with artifact sale even after the most environmentally and ethically responsible excavation, illustrate that purely state-centric approaches are inappropriate to the globalized world in which developing nations and their resource managers (or exploiters) operate. The Dominican government officially maintains complete control over the recovery of $\mathrm{UCH}$, yet this regulatory structure has ultimately led to unsustainable exploitation rather than the use of the resource for the benefit of all Dominicans. Furthermore, the Dominican government cannot suddenly begin to manage its $\mathrm{UCH}$ and associated natural resources in a way that the overarching international consensus for conservation would deem acceptable, even if it became a party to the 2001 Convention. The funding and technical skills simply do not exist within the state, nor can preservationists hope for a generation of professionally trained Dominican archaeologists to appear overnight. Likewise, the Dominican Republic has already found a way to capitalize on this resource through a function of globalization: specifically the ability - even of a state-to look outside of one's own borders for money and expertise absent at home. The Dominican resource management agencies are accustomed to foreign, nongovernmental participation in their activities (if not always happy about it); therefore, attempting to dismantle the general framework of these public-private and domesticforeign relationships would be counterproductive. ${ }^{137}$ Instead, it is more efficient to reframe these relationships using Indiana University's Living Museums in the Sea model as implemented through two other strategies for resource management in the globalized world: Ostromian Common-Pool Resource Management Theory and Multilevel Environmental Governance.

137. See Holmes, supra note 125, at 639 (Although foreign NGOs like the Nature Conservancy are extremely active in the Dominican Republic, "[t]he Nature Conservancy faces strong resistance from Dominican NGOs, the state and the media, who are very strongly opposed to its involvement in protected areas administration. This is based on a form of anti-US sentiment, part of wider Dominican opposition to US ownership of land: giving a US NGO a role in running a protected area is seen as a damaging attack on sovereignty"). 


\section{A. The Living Museums in the Sea Model}

Living Museums in the Sea is a multi-resource, sustainable management strategy developed by the Indiana University Office of Underwater Science. Inspired by the U.S. Department of Commerce National Oceanic and Atmospheric Administration's (NOAA) National Marine Sanctuary program, the Living Museums model protects UCH and the associated marine life by creating marine protected areas around the UCH site. ${ }^{138}$ Artifacts and their associated biology are predominately left in situ (when appropriate, thus avoiding the need for expensive conservation techniques), ${ }^{139}$ and professional archaeologists provide interpretive materials and train Dominicans as guides and park managers. ${ }^{140}$ These no-take, no-anchor zones can provide a consistent source of income (as opposed to the one-time gain from an artifact sale, which usually goes directly to the government and not the community from which the artifact was taken) from tourism and off-site fishing. ${ }^{141}$ Indiana University has already established three of these Living Museums on the south coast of the Dominican Republic without requiring the Dominican government to significantly alter the way it delegates management authority in the globalized context. ${ }^{142}$ Indiana University or other qualified noncommercial research and conservation programs assisting communities to implement the LMS model can replace treasure hunters as the specialist third parties to which the Dominican government delegates some of its management and

138. See generally Frederick H. Hanselmann \& Charles D. Beeker, Establishing Marine Protected Areas in the Dominican Republic: A Model for Sustainable Preservation, 2008 UNDERWATER ARCHAEOlogy PROC. FROM SOC'Y FOR HIST. ARCHAEOlOgY CONF. 52-61 (discussing the most effective way of preserving cultural and biological resources).

139. See Michael McCarthy, Museums and Maritime Archaeology, in THE OXFoRD HANDBOOK OF MARITIME ARCHAEOLOGY, supra note 9, at 1050-51 (stating that although in situ preservation should be considered as the primary option at any site, and that postexcavation conservation is "maritime archaeology's greatest hidden cost," artifact recovery must still be left open as an option when necessary due to threats to the artifact or the potential for significant scholarly benefit).

140. See Hanselmann \& Beeker, supra note 138.

141. Although fishing is not permitted within most marine protected areas, and never directly on the wreck site due to the danger of damage from fishing equipment, UCH serves as a fish-aggregating device that increases the population of fish in the general vicinity. See Brendan Foley, Impact of Fishing on Shipwrecks, WoODS HOLE OCEANOGRAPHIC INST., http://www.whoi.edu/sbl/liteSite.do?articleId=4965\&litesiteid=2740 (last visited Nov. 15, 2013).

142. See Charles BeEker \& Lauren Ayres, Living Museums in the SEA: Contributions to Conservation, Cultural Heritage, and Tourism Development IN THE DOMINICAN REPUBLIC 1 (2011); see also Herrera, supra note 122 (describing how Indiana University works in the Dominican Republic under the current permitting regime). 
monitoring responsibilities for significant UCH. However, ensuring this shift from private for-profit to private nonprofit management actually results in a long-term, equitable solution for the treatment of Dominican UCH requires critically analyzing it within the framework of Elinor Ostrom's principles for successful commons management.

\section{B. Treating UCH as an Ostromian Common-Pool Resource Using the LMS Model: Appropriate for the Dominican Context?}

UCH often fits the classic Ostromian model of a common-pool resource (CPR). It is characterized by high subtractability (removing artifacts from a shipwreck subtracts from the benefits that other users could gain from the site, from the artifacts as both cultural objects and substrate for marine life) and difficult exclusion (the inherently ephemeral and difficult-to-control nature of marine boundaries). ${ }^{143}$ As a result of decades of empirical field studies, Ostrom found that "no single type of property regime [open access, group, individual, or government] works efficiently, fairly, and sustainably in relation to all CPRs[, and] CPR problems continue to exist in many regulated settings," case in point: Dominican government owned-and-managed UCH.144 Instead, Ostrom identified seven principles common to successful, long-enduring CPR institutions, and an eighth unique to CPRs that are part of larger systems. ${ }^{145}$

Although Ostrom did not apply her factors directly to the challenge of archaeological resource management, there is precedent for treating cultural property as a type of CPR. Scholar Yan Zhang recommends using the Ostromian model to supplement management of terrestrial cultural resources in response to the shortcomings of privatization, state intervention, and international intervention. ${ }^{146}$ Treating a resource as simultaneously cultural and natural is not completely novel in the scholarly literature either. Professor Pammela Quinn Saunders suggested treating the natural resource rights of Maine lobstermen, which are managed as CPRs, as a form of cultural property to gain increased domestic and international legal recognition of their fishing

143. See Charlotte Hess \& Elinor Ostrom, Ideas, Artifacts, and Facilities: Information as a Common-Pool Resource 66 L. \& CoNTEMP. PROBS. 111, 120 (2003) (defining common-pool resources).

144. Elinor Ostrom et al., Revisiting the Commons: Local Lessons, Global Challenges, 284 SCIENCE 278, 279 (1999).

145. ElinOR OSTROM, GOVERNING THE COMMONS: THE EVOLUTION OF INSTITUTIONS FOR ColleCtive ACTION 90 (1990).

146. See Yan Zhang, Institutional Approach of Self-Governance on Cultural Heritage as Common Pool Resources 17 (Centro Studi Silvia Santagata-Int'l Ctr. for Research on the Econ. of Culture, Inst., and Creativity, Working Paper No. 22, 2010). 
practices as a property right. ${ }^{147}$ Yet, managing shipwrecks as both a cultural and natural resource is further complicated-particularly in the Dominican context-by the lack of a tradition of community management (of UCH) that typically characterizes successful CPR regimes. ${ }^{148}$ The development of a CPR management program in the Dominican context must therefore occur in a bi-directional way. Instead of external authorities harmonizing with organically created local property-management regimes to afford them legal protection, the Dominican model will involve communities appropriating and retooling foreign CPR-management strategies and the Dominican government altering, or at least reinterpreting, its national cultural resource legislation in response.

Applying Ostrom's first seven principles for successful CPR management to the Dominican natural and social landscape illustrates the particular advantages and challenges of creating this bi-directional CPR, and how the LMS model can help resolve these issues. ${ }^{149}$ Several of the principles should be considered together when they are helped and hindered by the same characteristics of the Dominican context and the LMS framework. The eighth factor will be addressed in the next section as a type of Multilevel Environmental Governance. At this point, it is important to reiterate that Living Museums envisions CPR as a tool for management rather than ownership of UCH. In accordance with both existing Dominican legislation and the overwhelming international consensus, the Dominican government would remain the ultimate owner of state-owned or abandoned UCH, with Dominican community members owning and managing access rights to the sites. ${ }^{150}$

\section{Principle 1: Clearly Defined Boundaries for Both the CPR and}

Those Who Have the Right to Use It; and Principle 2: Appropriation and Provision Rules Are Appropriate to the Local Conditions

Marine protected areas are notoriously difficult to govern, even in developed countries with well-funded management agencies and strong financial commitments to marine resource management. ${ }^{151}$ Recognizing

147. Pammela Quinn Saunders, A Sea Change Off the Coast of Maine: Common Pool Resources as Cultural Property, 60 EMORY L.J. 1324, 1372 (2011).

148. See OsTROM, supra note 145 , at 58-61.

149. See id. at 90 (stating all seven design principles illustrated by long-enduring CPR institutions).

150. See Decreto No. 289-99, supra note 99.

151. Peter J.S. Jones, Wanfei QIU \& Elizabeth De Santo, United Nations Env'T Programme, Governing Marine Protected areas: Getting the Balance Right 6 (2011). 
the utter impossibility of policing large areas of the ocean, the Living Museums concept requires resource managers to control only the area immediately surrounding the shipwreck or other UCH. ${ }^{152}$ Similar to the highly successful Florida Keys National Marine Sanctuary shipwreck trail, sites are designated with easily made marker buoys, and site managers maintain a system of mooring buoys so vessels carrying divers and snorkelers do not have to throw anchor and damage the site. ${ }^{153}$ Boundaries are, of course, only as good as the number of people who know about and respect them; therefore, community managers will have to network with the Dominican government to ensure that these areas are marked on nautical charts and to assist with compliance and enforcement.

Developing rules appropriate to the milieu for the use of shipwreck resources will involve a complicated dance among tour guides, fishermen, and archaeologists. These three groups of stakeholders are simultaneously in conflict with, yet dependent on, each other for long. term success. LMS sites cannot be created without the expertise--both for excavation and interpretation - of professional archaeologists and parks specialists to interpret the UCH and give it a sustainable monetary value as a unique tourist attraction. Archaeologists depend on tour guides and fishermen to abide by park rules so the sites retain their archaeological integrity. Tour guides require fishermen to abstain from fishing directly on the site to prevent harm to tourists from hooks, lines, and nets. Tour guides also prevent tourists from taking the marine life, which is one of the primary reasons why tourists dive in the first place. Archaeologists need tour guides to prevent tourists from taking artifacts and thereby destroying habitats. Appropriation and provision (which, in this case means site maintenance) of rights and duties must be structured to overcome the inevitably high transaction costs of consensus-building and compliance among different nationalities and professional classes. This will need to be accomplished through smaller, profession-specific CPRs to manage tour-boat access to sites and nearby, off-site fishing. ${ }^{154}$ Nonresident foreign stakeholders ${ }^{155}$

152. See Hanselmann \& Beeker, supra note 138.

153. See id.

154. Although fishing rights have long been governed by variants of CPR regimes outside the Dominican Republic, CPR fisheries management has interestingly been the most successful in the Dominican context when "external or non-fishing NGOs such as academics, international bodies, or advocacy groups" provide legitimacy to the CPR regime rules. Evelyn Pinkerton, Community-Based Management \& Co-management, OCEAN MANAGEMENT RESEARCH NETWORK (Nov. 7, 2003), http://www.maritimeawards.ca/ OMRN/pinkerton.html\#stouffle1994; See also Fikret Berkes, Success and Failure in Marine Coastal Fisheries of Turkey, in MAKING THE COMMONS WORK: THEORY PRACTICE AND PolicY 161, 161-62 (Daniel W. Bromley ed., 1992) (describing how sea tenure 
(i.e., university programs and other professional noncommercial archaeological programs), in addition to operating with the permission of the Dominican government, should also form partner agreements with the other appropriator groups.

\section{Principle 3: Collective Choice: Most Individuals Affected by the Resource Management Rules Can Participate in Modifying Those Rules; and Principle 7: External Governmental Authorities Respect the Rights of Resource Appropriators to Devise Their Own Rules}

Although logistically the simplest of the seven factors to implement, ensuring the rights of participation of Dominican community members and gaining the permission and recognition from the Dominican government as the resource managers with the absolutely critical right to exclude are the most politically challenging. The Dominican government has a long history of, although effective, relatively autocratic conservation strategies.156 Furthermore, the increasing economic reliance on tourism, which the LMS model would help advance, poses significant distributional justice problems if it continues to be executed using the traditional, elite-run model. ${ }^{157}$ The Dominican government explicitly stated that tourism development "is the highest priority of the Dominican State as an adequate measure for the advance of economic progress in the country," 158 and there is no guarantee that increased tourism will benefit the wider Dominican populace or be any less environmentally destructive than the current all-inclusive resort model. ${ }^{159}$ Yet, the very overreliance of the Dominican economy on

management of Mediterranean fisheries dates back to the ancient Sumerians). Treating dive shop tourists as a CPR has even gained some attention in the academic literature. See Lee Cronk \& Shannon Steadman, Tourists as a Common-Pool Resource: A Study of Dive Shops on Utila, Honduras, in ECONOMIC DEVELOPMENT: AN ANTHRopologicAl APPROACH 51, 63 (Jeffrey H. Cohen \& Norbert Dannhaeuser eds., 2002).

155. I specify "non-resident" because many dive shop owners in the Dominican Republic who are UCH stakeholders are foreign.

156. See generally Holmes, supra note 125 (discussing conservation as an elite process in the DR).

157. See Crawford, supra note 134 , at 56.

158. Decreto No. $395-98$, que declara de utilidad pública e interés social la adquisición por el Estado Dominicano de varias porciones de terreno en San Cristóbal, para ser destinadas a la sede del Instituto de Formación Turística del Caribe [Decree declaring the public utility and social interest of the acquisition by the Dominican State of several lots of land in San Cristóbal, to be used for the headquarters of the Tourism Institute of the Caribbean], G.O. No. 10004, del 31 de octubre de 1998 (Dom. Rep.) ("Que el desarrollo del turismo es de alta prioridad para el Estado Dominicano como medio adecuado para alcanzar el progreso económico del país.").

159. See Crawford, supra note 134, at 52-53, 57. 
tourism combined with the inherent complexity of managing marine resources described in Principles 1 and 2 could actually force the development and adoption of Principles 3 and 7. As the international tourism market moves away from the traditional sun-and-sand model, the Dominican government increasingly looks to ecotourism as the solution. ${ }^{160}$ While this model threatens to perpetuate the antidemocratic legacy of the Dominican conservation movement in terrestrial sites, the inherently chaotic nature of the marine space will require a much more decentralized, and hopefully more democratic, management structure. ${ }^{161}$

\section{Principle 4: Accountable Resource Monitors; Principle 5:}

Sanctions Are Graduated Depending on Seriousness of Offense; and

Principle 6: Low-Cost and Time-Sensitive Access to Conflict-

Resolution Mechanisms.

As already detailed in Part II, the Dominican Republic is unfortunately, and deservedly, reputed for its incredibly high level of corruption. ${ }^{162}$ However, the Dominican Republic also has a tradition of local organization springing up to take the place of dysfunctional or completely absent governmental action, even for notoriously difficult-tomanage marine resources. ${ }^{163}$ These independent, nongovernmental resource management strategies can also blossom into international partnerships. In the Samaná Bay region, an international NGO (the Washington, D.C. based Centre for Marine Conservation) implemented a collaborative coastal management program with no assistance or even recognition from the Dominican government. ${ }^{164}$ Unfortunately, this project has faced difficulties due to the lack of legitimization of local

160. See id. at $60,79-80$.

161. See light Carruyo, Producing Knowledge, Protecting Forests: Rural ENCOUNTERS WITH GENDER, ECOTOURISM, AND INTERNATIONAL AID IN THE DOMINICAN REPUBLIC 13-14, 27-28 (2008) (detailing how the José Armando Bermúdez National Park, a prime ecotourism destination in the mountainous center of the Dominican Republic, was created to rescue nature from the peasants).

162. See generally MEACHAM, supra note 16 (evaluating the current state of the rule of law, corruption, and judicial independence in the Dominican Republic).

163. See generally Brent W. Stoffle et al., Folk Management and Conservation Ethics Among Small-Scale Fishers of Buen Hombre, Dominican Republic, in FolK MANAGEMENT IN THE WORLD'S FISHERIES: LESSONS FOR MODERN FISHERIES MANAGEMENT 115, 115-38 (Christopher L. Dyer \& James R. McGoodwin eds., 1994) (describing how the community of Buen Hombre works to preserve the coral reef ecosystem and the local marine life in order to sustainably support the local community).

164. See Emma L. Tompkins, Development Pressures and Management Considerations in Small Caribbean Islands' Coastal Zones 15 (Ctr. for Soc. and Econ. Research on the Global Env't, Working Paper No. 8, 2003), available at http://www.cserge.ac.uk/sites/ default/files/ecm_2003_08.pdf. 
control from the Dominican government, illustrating the importance of Ostrom's seventh principle. ${ }^{165}$

Although Ostrom states that enforcement mechanisms must be internal to the CPR-appropriator group, 166 this principle must be implemented in a more flexible way given both the multinational character of UCH appropriators and the different aspects of the resource that they appropriate. Renewable resource takings disputes should ideally happen at the community level to reduce transaction costs and the opportunity for corruption to influence outcomes. The severity of the penalty could vary based on the relative nonrenewability of the resource. For example, fishing above one's quota, fishing at the wrong times, bringing divers to the site out of turn, or bringing too many divers to a site could result in an inconvenient but relatively minor sanction, while taking a slow-growing coral or sponge or repeat offenses could result in more severe penalties such as large fines, suspensions, and public opprobrium.

However, in a departure from traditional CPR-management theory, the unauthorized taking of the nonrenewable resource (the artifacts) must be resolved at the national level, as this type of infraction is often only discovered when the malfeasor attempts to take the artifact out of the country. ${ }^{167}$ Fortunately, there is already a strong international framework in place to deter the illicit trade in artifacts. ${ }^{168}$ The impetus is therefore on the Dominican government to declare and enforce all forprofit removal of artifacts as illegal, thereby subjecting treasure hunting to the hammers of national customs laws.

\section{No Justice, No Sustainability: Fulfilling Ostrom's Eighth Principle Through Multilevel Environmental Governance}

Ostrom's eighth principle of successful CPR institutions states that, for CPRs that are a part of larger systems, "governance activities [must be] organized in multiple layers of nested enterprise." 169 Although an individual shipwreck and the coral growing on it may only cover a few square meters of the sea floor, its stakeholders range from the local tour

165. See id; see also OSTROM, supra note 145 , at 90 .

166. See OSTROM, supra note 145 , at 95.

167. See, e.g., ICE and CBP return 67 artifacts to the Dominican Republic, U.S. IMMIGR. AND CUSTOMS ENFORCEMENT (Aug. 18, 2011), http://www.ice.gov/news/releases/1108/ 110818santodomingo.htm.

168. See, e.g., Convention on the Means of Prohibiting and Preventing the Illicit Import, Export and Transfer of Ownership of Cultural Property, adopted Nov. 14, 1970, 10 I.L.M. 289, 823 U.N.T.S. 232.

169. See OSTROM, supra note 145 , at 90. 
guide bringing his clients to the dive site to the fisherman working miles away whose catch spawned on the wreck, all the way to the upper echelons of the Dominican Ministries of Culture and Environment and the multitude of foreign tourists, would-be treasure hunters, scholars, and concerned governments. As Ostrom stated, "[e]stablishing rules at one level, without rules at the other levels, will produce an incomplete system that may not endure over the long run."170

Scholar Tun Myint echoed this concern in his study of multinational, polycentric river system governance, stating that to ensure successful implementation of local, national, and transnational (i.e., multilevel) environmental governance, nonstate actors must "cooperate and comply with transnational legal and policy arrangements at the local layer. . . ."171 In Myint's view, a critical aspect of creating successful multilevel governance is identifying "sources of legitimacy for these nonstate actors ... to be equal partners in the transnational layer of governance."172 Thus, it is not enough to implement a CPR management strategy. CPR management through LMS must be thought of as a type of Multilevel Environmental Governance due to the extreme power inequalities among the multitude of stakeholders.

As stated in the previous section, enforcement mechanisms are always internal to the user group in all successful CPR systems. ${ }^{173}$ Yet, as the user groups in the Dominican context become more internationalized due to the influx of tourism development and dollars, the resource monitors and users risk becoming less accountable to one another. The LMS model, as it inherently relies on tourism as an incentive mechanism to protect $\mathrm{UCH}$, must ensure that it is not complicit in the continued disenfranchisement of Dominicans from their natural resource access rights. ${ }^{174}$

The LMS model as a tool of Multilevel Environmental Governance (MLEG) has the potential to provide this source of legitimacy for Dominican nonstate actors so they can hold their own against governmental and foreign private entities. MLEG, defined as "nested levels of jurisdictions or the organisation of governance functions at

170. Id. at 102 .

171. Tun Myint, Governing International Rivers: Polycentric Politics in the MEKONG AND THE RHINE 39 (2012).

172. Id.

173. See OSTROM, supra note 145 , at 95 .

174. See generally Crawford, supra note 134 (examining the role of the U.S. in strengthening Dominican environmental protection). 
several spatial scales simultaneously,"175 helps overcome collective action problems in large, multi-layered systems by keeping the primary actor groups at each level small. For example, one Dominican fisherman who does not want a shipwreck that is his primary fishing ground to be looted has no chance going up against wealthy United States-based companies and their allies in the Dominican government, nor even his fellow fishermen if they see they can make a short-term profit by selling the location of the wreck to a treasure hunter. But, if he is part of a formalized local group that governs an aspect of the resource through Ostromian CPR with the recognition of the Dominican government, he can gain the legitimacy to participate in the global decision making. Fortunately, the Dominican legislation governing UCH already recognizes third-party managers through the same concession rights that currently allow treasure hunters to plunder Dominican waters. ${ }^{176}$ Therefore, it should not require significant legislative reform to substitute one manager (community members and their international partners) for another.

\section{CONCLUSION}

Unless a transnational, globalization-appropriate solution like the Living Museums in the Sea is proven to be a successful CPR management model, the Dominican model of "Command, Control, and Cash In" will increasingly appeal to lesser-developed countries as cultural protection laws harmonize in the "developed" world. Yet, in this era of austerity, we can expect all governments-both of developed and developing countries-to increase the horizontal outsourcing of their responsibilities to nonstate actors, not always for the public benefit. Community-based management of our underwater heritage is consequently imperative for the sustainable use of $\mathrm{UCH}$ for all mankind.

175. Jouni Paavola, Explaining Multi-Level Environmental Governance 5 (Sustainability

Research Inst., Working Paper No. 10, 2008), available at http://www.see.leeds.ac.uk/fileadmin/Documents/research/sri/workingpapers/SRIPs-10_01.pdf.

176. See Decreto No. 289.99, supra note 99, Art. 5 ("execute its program of study, salvage, conservation, and enhancement of artifacts through third-party concessions") (author's translation). 